OPEN ACCESS

Edited by:

Meixue Zhou,

University of Tasmania, Australia

Reviewed by:

Min Zhu,

Yangzhou University, China Nobuhiro Suzuki,

Sophia University, Japan

${ }^{*}$ Correspondence:

Jian Cai

caijian@njau.edu.cn

Dong Jiang

jiangd@njau.edu.cn

Specialty section: This article was submitted to

Plant Abiotic Stress,

a section of the journal

Frontiers in Plant Science

Received: 31 May 2017

Accepted: 07 July 2017

Published: 19 July 2017

Citation:

Si T, Wang $X$, Wu L, Zhao $C$, Zhang L, Huang M, Cai J, Zhou Q, Dai T, Zhu J-K and Jiang D (2017) Nitric Oxide and Hydrogen Peroxide Mediate Wounding-Induced Freezing

Tolerance through Modifications in Photosystem and Antioxidant

System in Wheat.

Front. Plant Sci. 8:1284.

doi: 10.3389/fpls.2017.01284

\section{Nitric Oxide and Hydrogen Peroxide Mediate Wounding-Induced Freezing Tolerance through Modifications in Photosystem and Antioxidant System in Wheat}

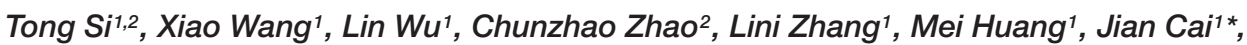
Qin Zhou' ${ }^{1}$, Tingbo Dai', Jian-Kang Zhu' ${ }^{2}$ and Dong Jiang ${ }^{1 *}$

${ }^{1}$ National Technique Innovation Center for Regional Wheat Production, Key Laboratory of Crop Physiology and Ecology in Southern China, Ministry of Agriculture, National Engineering and Technology Center for Information Agriculture, Nanjing Agricultural University, Nanjing, China, ${ }^{2}$ Department of Horticulture and Landscape Architecture, Purdue University, West Lafayette, IN, United States

Mechanical wounding is a common stress caused by herbivores or manual and natural manipulations, whereas its roles in acclimation response to a wide spectrum of abiotic stresses remain unclear. The present work showed that local mechanical wounding enhanced freezing tolerance in untreated systemic leaves of wheat plants (Triticum aestivum L.), and meanwhile the signal molecules hydrogen peroxide $\left(\mathrm{H}_{2} \mathrm{O}_{2}\right)$ and nitric oxide (NO) were accumulated systemically. Pharmacological study showed that wounding-induced NO synthesis was substantially arrested by pretreatment with scavengers of reactive oxygen species and an inhibitor of $\mathrm{NADPH}$ oxidase (respiratory burst oxidase homolog, $\mathrm{RBOH}$ ). On the contrary, wounding-induced $\mathrm{H}_{2} \mathrm{O}_{2}$ accumulation was not sensitive to $\mathrm{NO}$ synthetic inhibitors or scavenger, indicating that $\mathrm{H}_{2} \mathrm{O}_{2}$ acts upstream of $\mathrm{NO}$ in wounding signal transduction pathways. Cytochemical and vascular tissues localizations approved that $\mathrm{RBOH}$-dependent $\mathrm{H}_{2} \mathrm{O}_{2}$ acts as long-distance signal in wounding response. Transcriptome analysis revealed that 279 genes were up-regulated in plants treated with wounding and freezing, but not in plants treated with freezing alone. Importantly, freezing- and wounding-induced genes were significantly enriched in the categories of "photosynthesis" and "signaling." These results strongly supported that primary mechanical wounding can induce freezing tolerance in wheat through the systemic accumulation of $\mathrm{NO}$ and $\mathrm{H}_{2} \mathrm{O}_{2}$, and further modifications in photosystem and antioxidant system.

Keywords: mechanical wounding, hydrogen peroxide, nitric oxide, signaling, wheat, freezing tolerance

\section{INTRODUCTION}

As one of the major abiotic stresses, freezing causes adverse effects on crop physiological and metabolic processes (Chinnusamy et al., 2007; Ahuja et al., 2010; Kosová et al., 2013). Freezing is also a factor that causes agronomic yield losses under global climate change (IPCC, 2007). The production of winter wheat (Triticum aestivum L.) can be considerably destroyed by untimely frost 
or cold spell in later spring (Asseng et al., 2011; Han et al., 2013). As yet, the effects of freezing stress on crop production and mechanisms of freezing tolerance have been widely studied (Zhong et al., 2008; Kane et al., 2013; Trischuk et al., 2014; Jurczyk et al., 2015). However, the strategies of alleviating the negative effects of freezing stress and the potential mechanisms are still far from clear.

Hydrogen peroxide $\left(\mathrm{H}_{2} \mathrm{O}_{2}\right)$, one of the reactive oxygen species (ROS), acts as a central signal molecule that mediates plant abiotic resistance by enhancing the transcription of stress-responsive genes and antioxidant capacity especially in response to freezing stress (Neill et al., 2002; Torres and Dangl, 2005; Li et al., 2014a). $\mathrm{H}_{2} \mathrm{O}_{2}$ has also been implicated in the perception and transduction of stimuli signals to mediate plant physiological processes directly through long-distance signaling or indirectly through NADPH oxidase (respiratory burst oxidase homolog, $\mathrm{RBOH}$ ) in various species (Miller et al., 2009; Xia et al., 2015; Evans et al., 2016). In recent years, nitric oxide (NO) has drawn many attentions due to its integral role in response to various abiotic stresses such as freezing, wounding, salinity, metal toxicity, and UV (Zhao et al., 2004; Shi et al., 2005; Lin et al., 2011; Puyaubert and Baudouin, 2014; Sun et al., 2014). The cross-talk between $\mathrm{H}_{2} \mathrm{O}_{2}$ and $\mathrm{NO}$ in response to abiotic or biotic stresses is still in debate. $\mathrm{NO}$ causes rapid $\mathrm{H}_{2} \mathrm{O}_{2}$ accumulation when exposing plants to herbivore attacks, ozone or Tobacco Mosaic Virus infection, pointing out that $\mathrm{NO}$ acts upstream of $\mathrm{H}_{2} \mathrm{O}_{2}$ (Orozco-Cárdenas and Ryan, 2002; Pasqualini et al., 2009; Liao et al., 2013). Reversely, $\mathrm{H}_{2} \mathrm{O}_{2}$ regulates $\mathrm{NO}$ in response to abscisic acid (ABA) induced stomatal closure and aphids infestation (Bright et al., 2006; Mai et al., 2014). A deep investigation of the relationship between $\mathrm{H}_{2} \mathrm{O}_{2}$ and $\mathrm{NO}$ thus becomes a very fruitful avenue to uncover the underlying mechanisms that plants respond to various abiotic stresses.

Systemic acquired acclimation (SAA) has emerged as a protection mechanism against various abiotic stimuli, including heat, cold, high light, UV, and salinity in plants (Rossel et al., 2007; Mittler and Blumwald, 2015; Gilroy et al., 2016). Calcium waves, hydraulic waves, and electric signals are supposed to be early signals involved in this response. SAA, which is accompanied by a long-distance signaling response, cannot be induced without the participation of $\mathrm{H}_{2} \mathrm{O}_{2}$ and $\mathrm{NO}$ (Alvarez et al., 1998; Jih et al., 2003; Arasimowicz et al., 2009). Mechanical wounding, which is induced by biotic (e.g., herbivore attack and pathogens infection) and abiotic (e.g., raining, wind, touching, and hailing) factors in plants, exists widely in nature. Wounding induces numerous abiotic stress responses in untreated leaves or tissues involved in SAA (Schilmiller and Howe, 2005; Capiati et al., 2006; Walley et al., 2007; Mousavi et al., 2013). $\mathrm{H}_{2} \mathrm{O}_{2}$ and NO participate as pivotal signal messengers in response to wounding (OrozcoCárdenas and Ryan, 1999; Orozco-Cárdenas et al., 2001; París et al., 2007; Minibayeva et al., 2009), whereas their roles in wounding-induced adaptation responses to abiotic stresses are barely reported in the literatures. In consideration of the roles of $\mathrm{H}_{2} \mathrm{O}_{2}$ and $\mathrm{NO}$ in wounding response and the alleviation effects on freezing stress, it would be of great interest to investigate whether $\mathrm{H}_{2} \mathrm{O}_{2}$ and $\mathrm{NO}$ are pivotal hubs involved in woundinginduced freezing tolerance in untreated systemic leaves.
In our previous study, we have shown that mechanical stimulation is associated with cold responses in wheat by modifications in the chloroplast antioxidant system and proteome changes under field condition (Li et al., 2015). However, its in-depth mechanism remains obscure. This study was designed to investigate the mechanisms underlying the alleviation effects of mechanical wounding on freezing stress in untreated systemic leaves of wheat plants as well as the signaling transduction of wounding-induced $\mathrm{H}_{2} \mathrm{O}_{2}$ and $\mathrm{NO}$ between these leaves.

\section{MATERIALS AND METHODS}

\section{Plant Materials}

Uniform seeds of winter wheat (Triticum aestivum L. cv. Yangmai 16) were selected. Seeds were surface-sterilized using $2.5 \%$ sodium hypochlorite for $10 \mathrm{~min}$, rinsed five times with sterile distilled water and germinated in vermiculite. When the second leaf fully expanded, plants were transferred to plastic containers (45 cm in length, $35 \mathrm{~cm}$ in width, and $18 \mathrm{~cm}$ in height) with Hoagland's nutrient solution for hydroponic culture with the following experimental conditions: air temperature of $25^{\circ} \mathrm{C} / 18^{\circ} \mathrm{C}$ (day/night), a photoperiod of 14/10 h (day/night), a constant humidity of $80-90 \%$ and a photosynthetic photon flux density (PPFD) of around $600 \mu \mathrm{mol} \mathrm{m}^{-2} \mathrm{~s}^{-1}$. The solution was renewed daily and bubbled over the whole experimental period. Upon the appearance of the sixth fully expanded leaves (six-leaf stage), they were used for the experiment.

\section{Experimental Design Responses of Wheat Plants to Freezing Stress after Mechanical Wounding}

To determine the effect of mechanical wounding on resistance to freezing stress, the fourth leaves (we termed local leaves) from the bottom of seedlings at the six-leaf stage were wounded according to the methods of Capiati et al. (2006) and Gaupels et al. (2016) with appropriate modifications. The main vein in the center of the fourth leaves was crushed five times with a hemostat and the interval of each injury was $10 \mathrm{~mm}$. The strength of the crushing was made uniformly to each plant. Wounding did not cause any visible alterations such as necrosis around the injuries. Both wounded and unwounded plants were then divided into two equal groups for normal or low temperature treatments after $12 \mathrm{~h}$ of the wounding events. The freezing stress was conducted in the climate chamber at $-2^{\circ} \mathrm{C}$, while the normal temperature treatment was conducted in another chamber at $25^{\circ} \mathrm{C}$. The photoperiod was set at $12 / 12 \mathrm{~h}$ (day/night) and PPFD was set at $600 \mu \mathrm{mol} \mathrm{m}^{-2} \mathrm{~s}^{-1}$ during the day time.

The maximal photochemical efficiency of photosystem II $(F \mathrm{v} / F \mathrm{~m})$, net photosynthetic rate $(\mathrm{Pn})$, malondialdehyde (MDA) content and relative electrolyte conductivity (REC) were determined by the fifth leaves (we termed systemic leaves) as area of interest after $24 \mathrm{~h}$ freezing stress. In order to investigate the time-course of antioxidant system in response to mechanical wounding, the local leaves were prior wounded, then the local 
and systemic leaves of wounded and untreated plants were immediately harvested in liquid nitrogen at indicated times from 0 to $96 \mathrm{~h}$ to determine the activities of antioxidant enzymes.

\section{Effect of $\mathrm{H}_{2} \mathrm{O}_{2}$ and $\mathrm{NO}$ on Freezing Tolerance Induced by Mechanical Wounding}

To detect the involvement of $\mathrm{H}_{2} \mathrm{O}_{2}$ and $\mathrm{NO}$ in woundinginduced freezing tolerance, the systemic leaves were firstly foliar applied with $200 \mu \mathrm{M}$ sodium nitroprusside (SNP, a NO donor), $200 \mu \mathrm{M} \mathrm{N}{ }^{\mathrm{G}}$-nitro-L-Arg methyl ester (L-NAME, an inhibitor of NOS-type enzyme), $200 \mu \mathrm{M}$ tungstate (an inhibitor of NR), $200 \mu \mathrm{M}$ 2-(4-Carboxyphenyl)-4,4,5,5-tetramethylimidazoline1-oxyl 3-oxide (c-PTIO, a specific NO scavenger), $5 \mathrm{mM}$ dimethylthiourea (DMTU, a $\mathrm{H}_{2} \mathrm{O}_{2}$ and $\mathrm{OH}$ - scavenger) or $100 \mu \mathrm{M}$ diphenyleneiodonium (DPI, a RBOH inhibitor). After $8 \mathrm{~h}$ full absorption, the local leaves were wounded as mentioned above. After a time interval of $12 \mathrm{~h}$, one batch of the local and systemic leaves was collected and the activities of antioxidant enzymes as well as the expressions of their corresponding genes were analyzed. The other batch of the plants was exposed to freezing stress at $-2 \mathrm{C}$ for $24 \mathrm{~h} . \mathrm{Fv} / \mathrm{Fm}$ was then measured at $24 \mathrm{~h}$ on the systemic leaves. For time-course analysis of mechanical wounding and SNP induced changes in the tolerance to freezing stress, the local leaves were first treated with distilled water, $200 \mu \mathrm{M}$ SNP or wounded. Freezing was started at indicated times by challenged at $-2^{\circ} \mathrm{C}$ as mentioned above after water, SNP or wounding treatment. $F \mathrm{~V} / F \mathrm{~m}$ was then determined by the systemic leaves after $24 \mathrm{~h}$ freezing stress.

\section{The Relation of $\mathrm{H}_{2} \mathrm{O}_{2}$ and $\mathrm{NO}$, and Their Sources in Response to Mechanical Wounding}

To investigate the interrelation of wounding-induced $\mathrm{H}_{2} \mathrm{O}_{2}$ and $\mathrm{NO}$, the local leaves were pre-treated with $200 \mu \mathrm{M} \mathrm{L}-\mathrm{NAME}$, $200 \mu \mathrm{M}$ tungstate, $200 \mu \mathrm{M}$ c-PTIO, $5 \mathrm{mM}$ DMTU, or $100 \mu \mathrm{M}$ DPI. Eight hours after spraying, the local leaves were wounded as described previously. Three hours later, the local and systemic leaves were used for cytochemical and histochemical detection or chemical quantification of $\mathrm{H}_{2} \mathrm{O}_{2}$ and NO. In addition, the local and systemic of wounded leaves as well as their corresponding control were collected at indicated times from 0 to $96 \mathrm{~h}$ after wounding treatment and used for the chemical quantification of $\mathrm{H}_{2} \mathrm{O}_{2}$ and NO. In order to investigate the sources of $\mathrm{H}_{2} \mathrm{O}_{2}$ and $\mathrm{NO}$ in response to wounding, one batch of the wounded and control leaves was collected at 3 and $18 \mathrm{~h}$ after wounding for analyzing the NR and NOS activities, while the other batch was harvested at $3 \mathrm{~h}$ for cytochemical detection of $\mathrm{H}_{2} \mathrm{O}_{2}$ and gene expression analysis of $\mathrm{RBOH}$.

\section{Leaf Net Photosynthetic Rate and Chlorophyll Fluorescence}

Net photosynthetic rate $(\mathrm{Pn})$ was determined on systemic leaves after $1 \mathrm{~h}$ recovery after freezing treatment, using a portable photosynthesis system (LI-6400; LI-Cor, Lincoln, NE, United States). The air temperature, relative humidity, ambient $\mathrm{CO}_{2}$ concentration and photosynthetically active radiation (PAR) used in the measurement were $25^{\circ} \mathrm{C}, 85 \%, 380 \mu \mathrm{mol} \mathrm{mol}{ }^{-1}$ and $1000 \mu \mathrm{mol} \mathrm{m}{ }^{-2} \mathrm{~s}^{-1}$, respectively. Chlorophyll fluorescence was detected by an imaging system (CF Imager; Technologica Ltd., United Kingdom) as described in our previous research (Li et al., 2014b). For the maximal photochemical efficiency of photosystem II $(F \mathrm{v} / \mathrm{Fm})$, plants were dark-adapted for approximately $30 \mathrm{~min}$ before imaging and reading. $\mathrm{Fv} / \mathrm{Fm}$ was imaged on systemic leaves with the whole leaf as area of interest and analyzed by the FluorImager software (Version 2.2; Technologica Ltd., United Kingdom).

\section{NO Detection and Quantification}

Endogenous NO level was in situ detected by imaging the fluorescence of 4,5-diaminofluorescein diacetate (DAF-2DA, a highly specific molecular probe for NO) as described by Zhang et al. (2007). Wheat leaf squares $(10 \mathrm{~mm})$ were incubated in the buffer solution containing $10 \mu \mathrm{M}$ DAF-2DA (prepared in $20 \mathrm{mM}$ HEPES-NaOH, $\mathrm{pH}$ 7.4) and vacuum-infiltrated for $3 \mathrm{~h}$ in darkness at $25^{\circ} \mathrm{C}$, and then washed thoroughly with the same buffer for $10 \mathrm{~min}$ to remove excess fluorophore. Finally, the leaves were visualized with a confocal laser scanning microscope system (CLSM; TCS-SP2; Leica Lasertechnik GmbH, Heidelberg, Germany) (excitation $495 \mathrm{~nm}$; emission $515 \mathrm{~nm}$ ). NO content was further determined by following the conversion of oxyhemoglobin $\left(\mathrm{HbO}_{2}\right)$ to methemoglobin (MetHb) at $401 \mathrm{~nm}$ and $421 \mathrm{~nm}$ with a hemoglobin method as described by Pasqualini et al. (2009).

\section{ROS Histochemical Detection, Cytochemical Analysis, and Quantification}

The histochemical staining of $\mathrm{H}_{2} \mathrm{O}_{2}$ production was monitored according to Thordal-Christensen et al. (1997) with some improvements. Leaf samples were immediately immersed in $1 \mathrm{mg} \mathrm{mL}^{-1} 3,3^{\prime}$-diaminobenzidine (DAB) solution (prepared in $50 \mathrm{mM}$ Tris-acetate, $\mathrm{pH} 3.8$ ), vacuum-infiltrated for $10 \mathrm{~min}$ and incubated for $12 \mathrm{~h}$ at $25^{\circ} \mathrm{C}$ under light. Then the leaves were bleached in $95 \%(\mathrm{v} / \mathrm{v})$ boiled alcohol for $10 \mathrm{~min}$ to visualize the brown spots. After cooling down, photographs were taken using a microscope (IX71, Olympus Co., Tokyo, Japan). The $\mathrm{O}_{2}^{-\bullet}$ visual detection was monitored by the reaction of $\mathrm{O}_{2}^{-} \bullet$ and nitro blue tetrazolium (NBT) as originally described by Jabs et al. (1996). In total, the leaves were maintained in $2 \mathrm{mM} \mathrm{NBT}$ solution $(50 \mathrm{mM}$ Tris- $\mathrm{HCl}$ buffer, $\mathrm{pH}$ 6.1) and incubated at $25^{\circ} \mathrm{C}$ in dark. After $8 \mathrm{~h}$ fully reaction, the leaves were bleached in 95\% (v/v) boiled alcohol for $10 \mathrm{~min}$ prior to photographed.

$\mathrm{H}_{2} \mathrm{O}_{2}$ was also detected by a confocal laser scanning microscope system (CLSM; TCS-SP2; Leica Lasertechnik GmbH, Heidelberg, Germany) as mentioned by Xia et al. (2011) with minor modifications. For the fully absorption of the chemicals in the whole plant, the roots of the seedlings were incubated overnight in the climate chamber at $25^{\circ} \mathrm{C}$ with $25 \mu \mathrm{M} 2^{\prime}, 7^{\prime}$ dichlorofluorescein diacetate (H2DCF-DA), prepared in $20 \mathrm{mM}$ HEPES-NaOH ( $\mathrm{pH}$ 7.4). The leaves and sheaths were sliced $3 \mathrm{~h}$ after each treatment with a couple of blades. The cross-sections were then washed with the $20 \mathrm{mM}$ HEPES-NaOH (pH 7.4) buffer for $20 \mathrm{~min}$ to remove excess fluorophore. Then, the cross-sections 
were transferred to glass slides mounted in glycerol:phosphatebuffered saline $(1: 1 \mathrm{v} / \mathrm{v})$ and immediately examined with a CLSM (excitation $488 \mathrm{~nm}$; emission $525 \mathrm{~nm}$ ).

The cytochemical localization of $\mathrm{H}_{2} \mathrm{O}_{2}$ was conducted using the cerium trichloride $\left(\mathrm{CeCl}_{3}\right)$ staining protocol according to Bestwick et al. (1997). The excised leaf tissue pieces (1-2 $\left.\mathrm{mm}^{2}\right)$ were incubated in freshly prepared $5 \mathrm{mM} \mathrm{CeCl}_{3}$ solution $(50 \mathrm{mM}$ 3-(N-mor-pholino) propanesulfonic acid (MOPS) buffer, $\mathrm{pH}$ 7.2) for $1 \mathrm{~h}$. The leaf sections were then fixed in $1.25 \%(\mathrm{v} / \mathrm{v})$ glutaraldehyde and $1.25 \%(\mathrm{v} / \mathrm{v})$ paraformaldehyde buffer $(50 \mathrm{mM}$ sodium cacodylate, $\mathrm{pH}$ 7.2) for $8 \mathrm{~h}$. After fixation, the tissues were washed twice in the same buffer and postfixed for $45 \mathrm{~min}$ in $1 \%(\mathrm{v} / \mathrm{v})$ osmium tetroxide. Then the samples were dehydrated in a graded ethanol series (30-100\%; v/v) and embedded in Eponaraldite (Agar Aids, Bishop's Stortford, United Kingdom). After $12 \mathrm{~h}$ in pure resin, followed by a change of fresh resin for $4 \mathrm{~h}$, the tissues were polymerized at $60^{\circ} \mathrm{C}$ for $48 \mathrm{~h}$. The sections were then sectioned $(70-90 \mathrm{~nm})$ on a Reichert-Ultracut E microtome and mounted on uncoated copper grids (300 mesh). The blocks were ultimately examined at subcellular level using a transmission electron microscope (H7650; Hitachi, Tokyo, Japan) at an accelerating voltage of $80 \mathrm{kV}$.

The concentration of $\mathrm{H}_{2} \mathrm{O}_{2}$ was determined according to Willekens et al. (1997) by monitoring the absorbance of titanium peroxide complex at $410 \mathrm{~nm} . \mathrm{O}_{2}^{-} \bullet$ production rate was measured according to Elstner and Heupel (1976) at an absorbance at $530 \mathrm{~nm}$.

\section{Oxidative Damage Measurement}

Leaf lipid peroxidation was determined by measuring the amount of MDA produced by the thiobarbituric acid (TCA) reaction as mentioned by Hodges et al. (1999). MDA content was calculated at $532 \mathrm{~nm}$ by subtracting the absorbance at $600 \mathrm{~nm}$ for nonMDA compounds. The electrolytic conductivity was conducted according to Griffith and Mclntyre (1993) with a conductivity bridge (DDS-307A, LEX Instruments Co., Ltd., China) before (C1) and after (C2) the leaves were boiled for $30 \mathrm{~min}$. REC was calculated by the equation as: $\mathrm{REC}=\mathrm{C} 1 / \mathrm{C} 2 * 100 \%$.

\section{NOS and NR Activity Assay}

To assess NOS activity, the total protein was first measured as described by Jin et al. (2011). NOS activity was then measured after centrifugation at $13,000 \times g$ for $20 \mathrm{~min}$ at $4^{\circ} \mathrm{C}$ as in González et al. (2012). Briefly, NOS activity was detected in $1 \mathrm{~mL}$ of reaction mixture containing $100 \mathrm{mM}$ phosphate buffer ( $\mathrm{pH} 7.0$ ), $1 \mathrm{mM} \mathrm{L-}$ Arg, $2 \mathrm{mM} \mathrm{MgCl}_{2}, 0.3 \mathrm{mM} \mathrm{CaCl}_{2}, 4 \mu \mathrm{M} \mathrm{BH}_{4}, 1 \mu \mathrm{M} \mathrm{FAD}, 1 \mu \mathrm{M}$ flavin mononucleotide (FMN), $0.2 \mathrm{mM}$ DTT, $0.2 \mathrm{mM} \mathrm{NADPH}$ and $200 \mu \mathrm{L}$ of protein extract. The decrease in absorbance as a result of NADPH consumption was determined at $340 \mathrm{~nm}$ for 5 min. NOS activity was calculated using the extinction coefficient of NADPH.

The NR activity was assayed according to the method of Scheible et al. (1997) with some modifications. NR activity was performed by mixing one volume of extract with five volumes of $25^{\circ} \mathrm{C}$ prewarmed assay buffer containing $100 \mathrm{mM}$ HEPES$\mathrm{NaOH}$ ( $\mathrm{pH} 7.5$ ), $5 \mathrm{mM} \mathrm{KNO}_{3}$, and $0.25 \mathrm{mM} \mathrm{NADH}$. The reaction was started by the adding assay buffer, incubated at $25^{\circ} \mathrm{C}$ for
$30 \mathrm{~min}$, and then stopped by adding $0.1 \mathrm{M}$ zinc acetate. After $15 \mathrm{~min}$, the tubes were centrifuged at $13,000 \mathrm{~g}$ for $10 \mathrm{~min}$. The nitrite produced was measured at $520 \mathrm{~nm}$ by adding $1 \mathrm{~mL}$ of $1 \%(\mathrm{w} / \mathrm{v})$ sulfanilamide in $3 \mathrm{M} \mathrm{HCl}$ plus $1 \mathrm{~mL}$ of $0.02 \%(\mathrm{v} / \mathrm{v})$ $\mathrm{N}$-(1-naphthyl) - ethylenediamine in distilled water.

\section{Antioxidant Enzyme Extraction and Activity Assay}

Frozen leaf tissues ( $0.5 \mathrm{~g}$ FW) were ground in $5 \mathrm{~mL}$ ice-cold $25 \mathrm{mM}$ HEPES-NaOH buffer ( $\mathrm{pH} 7.8$ ) containing 20\% (v/v) glycerol, $1 \mathrm{mM}$ EDTA, $1 \mathrm{mM}$ ascorbic acid (AsA), $5 \mathrm{mM}$ $\mathrm{MgCl}_{2}, 1 \mathrm{mM}$ reducing glutathione (GSH) and $1 \mathrm{mM}$ DTT. The homogenates were centrifuged at $4^{\circ} \mathrm{C}$ for $20 \mathrm{~min}$ at $12,000 \mathrm{~g}$ and the resulting supernatants were collected for enzyme analysis. In addition, the protein content were determined as mentioned by Bradford (1976). Superoxide dismutase (SOD) activity was determined by measuring the ability to inhibit the photochemical reduction of NBT according to Stewart and Bewley (1980). One unit of SOD activity was defined as the amount of enzyme required to cause $50 \%$ inhibition of the reduction of NBT at $560 \mathrm{~nm}$. Catalase (CAT) activity was assayed as a decrease at $240 \mathrm{~nm}$ following the method of Patra et al. (1978). Ascorbate peroxidase (APX) activity was performed by a decline at $290 \mathrm{~nm}$ as previously described (Nakano and Asada, 1981) with minor modifications. Glutathione reductase (GR) activity was modified depending on the rate of decrease in the absorbance of NADPH at $340 \mathrm{~nm}$ as originally described by Foyer and Halliwell (1976).

\section{Extraction of Total RNA and Semi-quantitative RT-PCR Analysis}

Total RNA was isolated from wheat leaves using the Trizol reagent according to the procedure supplied by the manufacturer and dissolved in diethyl pyrocarbonate-treated water after extraction. The first-strand cDNA template for RT-PCR was synthesized from $2 \mu \mathrm{g}$ of total RNA following the manufacturer's instructions (Sangon, Shanghai, China). The RT-PCR were performed using $2 \mu \mathrm{L}$ two-fold diluted cDNA, $10 \mathrm{pmol}$ of each oligo nucleotide primer and $1 \mathrm{U}$ of Taq polymerase (Takara, Dalian, China) in $25 \mu \mathrm{L}$ reaction solution. The gene-specific primers were constructed based on their cDNA sequences and were used for amplification as listed in Supplementary Table S1. The optimum PCR cycle number was adjusted for each gene in preliminary experiments. The aliquots of PCR products were loaded and separated onto agarose gels (2\%) stained with ethidium bromide.

\section{High-Throughput mRNA Sequencing Analysis}

Four treatments of systemic leaves: control (ck), $3 \mathrm{~h}$ after wounding (wo), $24 \mathrm{~h}$ after freezing (fr) and $3 \mathrm{~h}$ wounding $+24 \mathrm{~h}$ freezing (wo_fr) were collected and total RNA was extracted as mentioned above for library construction and mRNA sequencing. The mRNA sequencing analysis was conducted in Shanghai Center for Plant Stress Biology, Chinese Academy of Sciences. Reads of RNA-seq data were mapped to wheat reference genome (Triticum_aestivum. TGACv1.30). Differentially expressed genes 
were defined based on the default of Cuffdiff (used for analyzing transcriptome assembly and differential expression of RNA-Seq in this paper). All results were average of three biological replicates. GO enrichment analysis was performed by AgriGO. The histogram was generated using $\mathrm{R}^{1}$. Raw Illumina sequences and assembled sequences are available in the Gene Expression Omnibus (GEO) database of the National Center for Biotechnology Information (NCBI) (accession number: SRP110839).

\section{Statistical Analyses}

Data were statistically analyzed by the SPSS software (version 11.0; SPSS Inc., Chicago, IL, United States). One-way ANOVA was used on the data sets and tested for significant $(P<0.05$ and $P<0.01)$ treatment differences using Tukey's test.

${ }^{1}$ https://www.r-project.org/

\section{RESULTS}

\section{Wounding Induces Freezing Tolerance Systemically in Wheat Plants}

Our first objective of this study was to determine whether mechanical wounding enhances freezing tolerance in wheat seedlings. Local leaves were prior wounded and the whole plants were further subjected to a $24 \mathrm{~h}$ freezing stress. Fluorescence images revealed that freezing treatment markedly decreased $\mathrm{Fv} / \mathrm{Fm}$ in the fifth leaves from the bottom of the wheat plants (called systemic leaves) in unwounded plants compared to control (Figure 1A). Nevertheless, prior wounded plants sharply restored in $\mathrm{Fv} / \mathrm{Fm}$ of systemic leaves in response to freezing stress. Besides, net photosynthetic rate (Pn) was determined after $24 \mathrm{~h}$ freezing treatment to assess the effect of mechanical wounding on freezing tolerance. Freezing stress

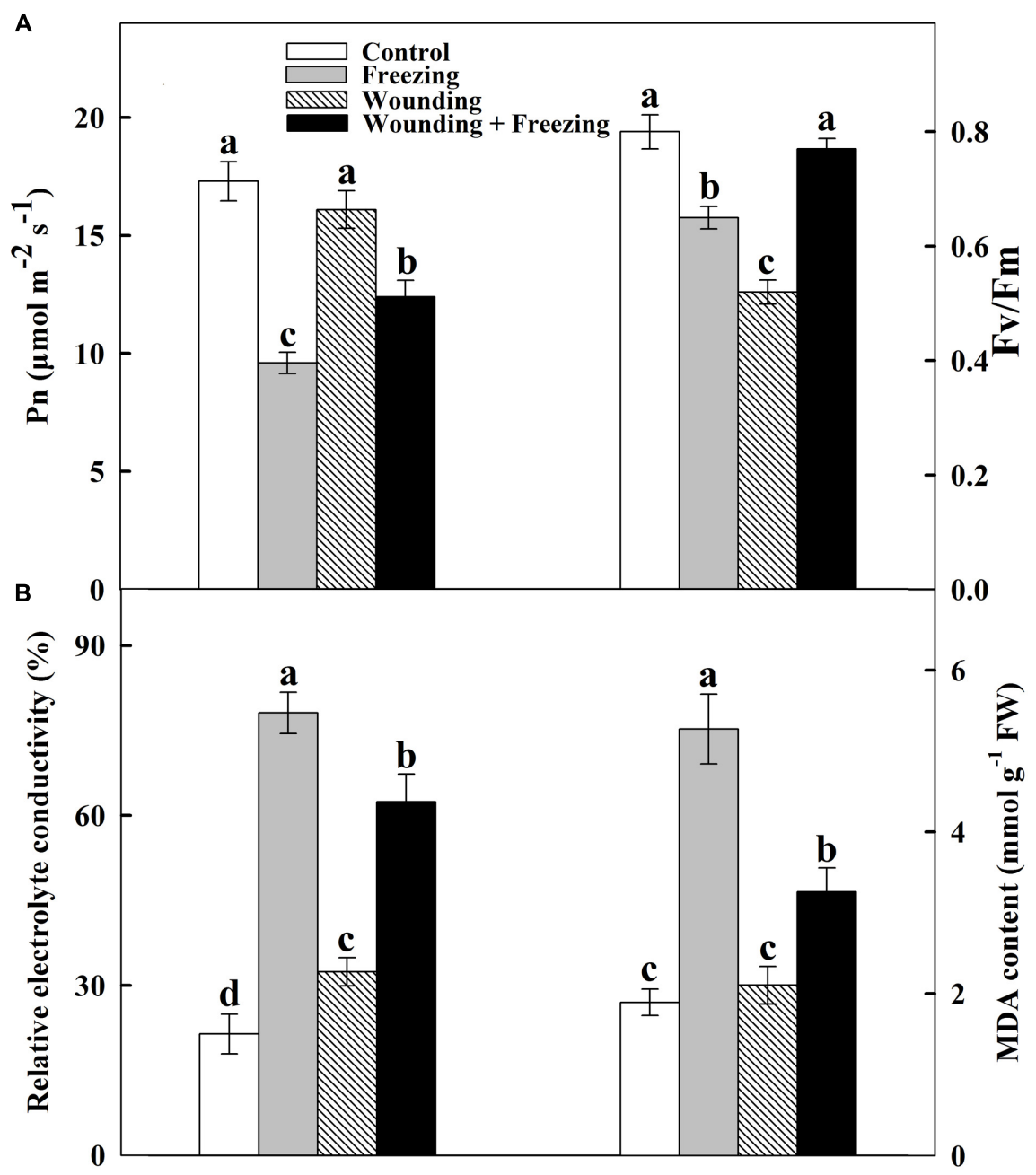

FIGURE 1 | Effect of mechanical wounding of the local leaf on the maximal photochemical efficiency of photosystem II (Fv/Fm) and net photosynthetic rate (Pn), and the relative electrolyte conductivity (REC) and content of malondialdehyde (MDA) in the systemic leaf of wheat. The local (fourth) leaf was wounded $3 \mathrm{~h}$ prior to exposed to the freezing stress for $24 \mathrm{~h}$. FV/Fm and Pn of the systemic (fifth) leaf were determined as area of interest after freezing stress (A). The systemic leaves were harvested after freezing stress for measurements of REC and MDA content (B). Data are means \pm SD of three different replicates. Means denoted by the same letter did not significantly differ at $P<0.05$ for each analysis according to Tukey's test. 
caused a significant reduction in Pn in untreated plants. Local mechanical wounding alleviated freezing stress in systemic leaves accompanied by increased Pn compared to unwounded plants. In addition, mechanical wounding has no influence on $\mathrm{Pn}$ in wounded-only plants compared to that of control (Figure 1A).

We also examined the role of mechanical wounding in plant responses to freezing stress by comparing the REC and lipid peroxidation based on the MDA content after $24 \mathrm{~h}$ freezing treatment. REC and MDA content were remarkably increased by freezing stress in systemic leaves of unwounded plants whereas those in local wounded plants were declined but were still maintained in a relative high level compared to that of control and wounded-only plants (Figure 1B), indicating that mechanical wounding plays dominant roles in reducing membrane lipid peroxidation under freezing stress. These results revealed a novel role of local mechanical wounding on enhancing tolerance to freezing stress systemically in wheat plants.

\section{Involvement of $\mathrm{H}_{2} \mathrm{O}_{2}$ in Wounding-Induced NO Production}

To detect the interaction of $\mathrm{NO}$ and $\mathrm{H}_{2} \mathrm{O}_{2}$ in response to mechanical wounding in wheat seedlings, we pre-treated the local leaves with L-NAME (an inhibitor of NOS), tungstate (an inhibitor of NR), c-PTIO (a specific NO scavenger), DPI (an inhibitor of $\mathrm{RBOH}$ ), or DMTU ( $\mathrm{H}_{2} \mathrm{O}_{2}$ and $\mathrm{OH} \cdot$ scavenger) prior to wound treatment for $8 \mathrm{~h}$. As shown in Figures 2A,B, pretreatment of L-NAME, tungstate or c-PTIO almost completely blocked wounding-induced NO accumulation in local leaves. Again, pre-treatment of DMTU or DPI substantially reduced wounding-induced NO level. In contrast, pre-treatment of plants with DMTU or DPI thoroughly scavenged $\mathrm{H}_{2} \mathrm{O}_{2}$ and $\mathrm{O}_{2}^{-} \bullet$ in local leaves as expected. In reverse, pre-treatment of L-NAME, tungstate or c-PTIO had no effects on $\mathrm{H}_{2} \mathrm{O}_{2}$ content and $\mathrm{O}_{2}^{-} \bullet$ production rate (Figures $2 \mathbf{B}-\mathbf{D}$ ). Based on these observations, $\mathrm{H}_{2} \mathrm{O}_{2}$ appears to act upstream of $\mathrm{NO}$ in response to mechanical wounding. Namely, the generation of ROS including $\mathrm{H}_{2} \mathrm{O}_{2}$ and $\mathrm{O}_{2}^{-\bullet}$ is essential for wounding-induced the accumulation of NO.

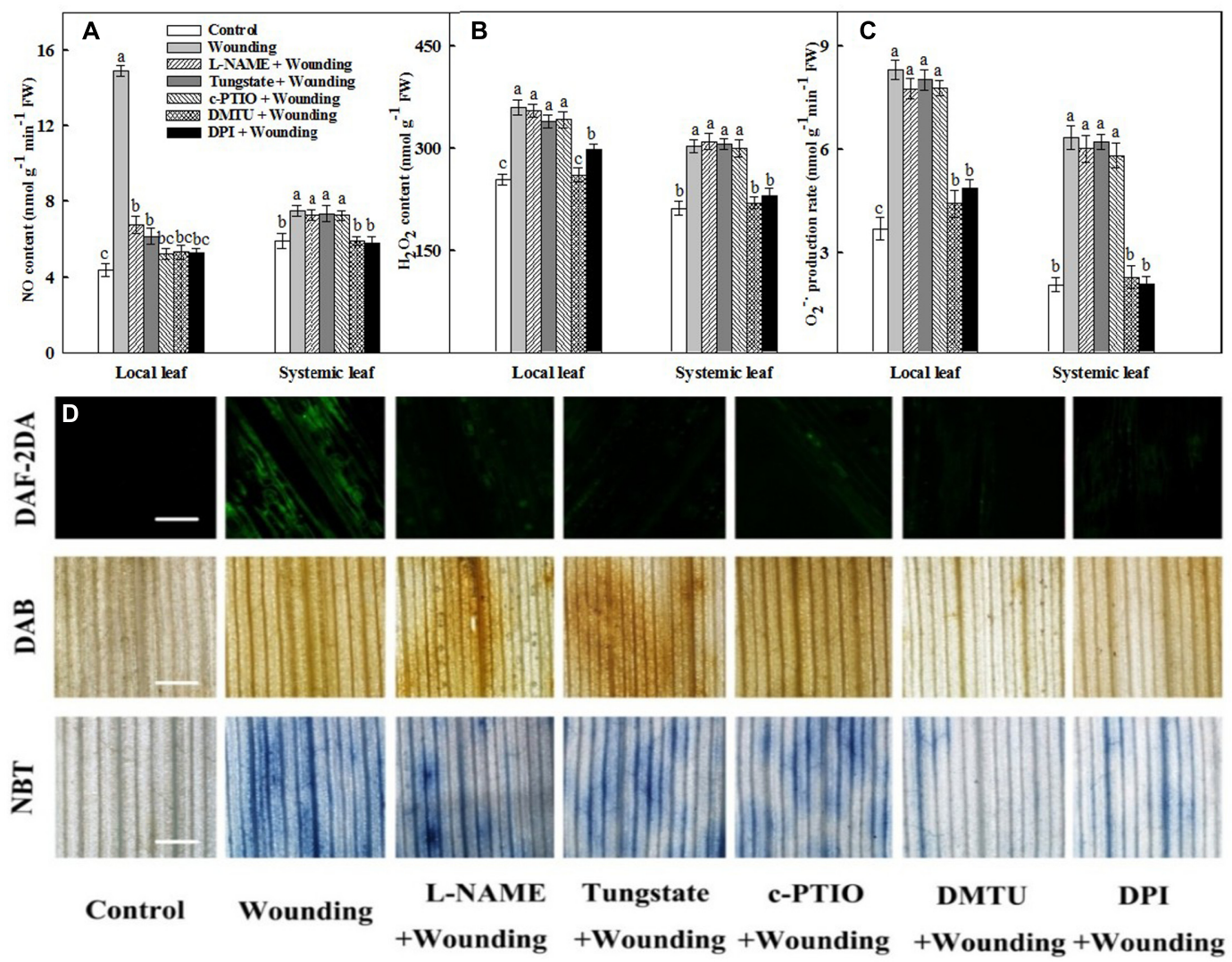

FIGURE 2 | Mechanical wounding-induced the accumulation of $\mathrm{NO}, \mathrm{H}_{2} \mathrm{O}_{2}$, and $\mathrm{O}_{2}^{-} \bullet$ in local leaf and systemic leaf. The local (fourth) leaf was pre-treated with distilled water, $200 \mu \mathrm{M}$ L-NAME, $200 \mu \mathrm{M}$ tungstate, $200 \mu \mathrm{M}$ c-PTIO, 5 mM DMTU, or $100 \mu \mathrm{M}$ DPI prior to wounding. The local leaves were harvested $3 \mathrm{~h}$ after wounding and the in situ NO was determined using DAF-2DA and detected by a confocal laser scanning microscope system (CLSM). The green fluoresce intensity of DAF-2DA indicates the degree of $\mathrm{NO}$ accumulation. Bar, $100 \mu \mathrm{m}$. $\mathrm{H}_{2} \mathrm{O}_{2}$ and $\mathrm{O}_{2}^{-}$were determined in local leaf by incubating in DAB or $\mathrm{NBT}$ and photographed with a microscopy. Images of DAB and NBT stained leaves showing localized $\mathrm{H}_{2} \mathrm{O}_{2}$ and $\mathrm{O}_{2}^{-} \bullet$ accumulation as dark-brown and dark-blue spots, respectively. Bars, $2 \mathrm{~mm}$. At least five leaves were imagined for each replicate and one representative is shown (D). The other batch of local and systemic (fifth) leaves was also collected and $\mathrm{NO}$ concentration (A), $\mathrm{H}_{2} \mathrm{O}_{2}$ content (B) as well as $\mathrm{O}_{2}^{-} \cdot$ production rate (C) were determined. Means denoted by the same letter did not significantly differ at $P<0.05$ for each treatment according to Tukey's test. 


\section{NO Is Involved in Wounding-Induced Freezing Tolerance}

Nitric oxide content was rapidly elevated systemically after wounding, suggesting that it may play a profound role in the subsequent freezing tolerance. To address this possibility, the NO donor SNP, synthesis inhibitors L-NAME, tungstate, and scavenger c-PTIO were applied to treat plants. The freezing tolerance was evaluated by measuring the reduction of $\mathrm{Fv} / \mathrm{Fm}$. Both wounding and SNP pre-treatment alleviated freezinginduced decline of $\mathrm{Fv} / \mathrm{Fm}$ in systemic leaves (Figure 3). In plants pre-treated with L-NAME, tungstate or c-PTIO, however, the $\mathrm{Fv} / F \mathrm{~m}$ was substantially decreased after freezing treatment. These results suggest that NO is essential for strengthening the photosynthetic system under freezing stress.
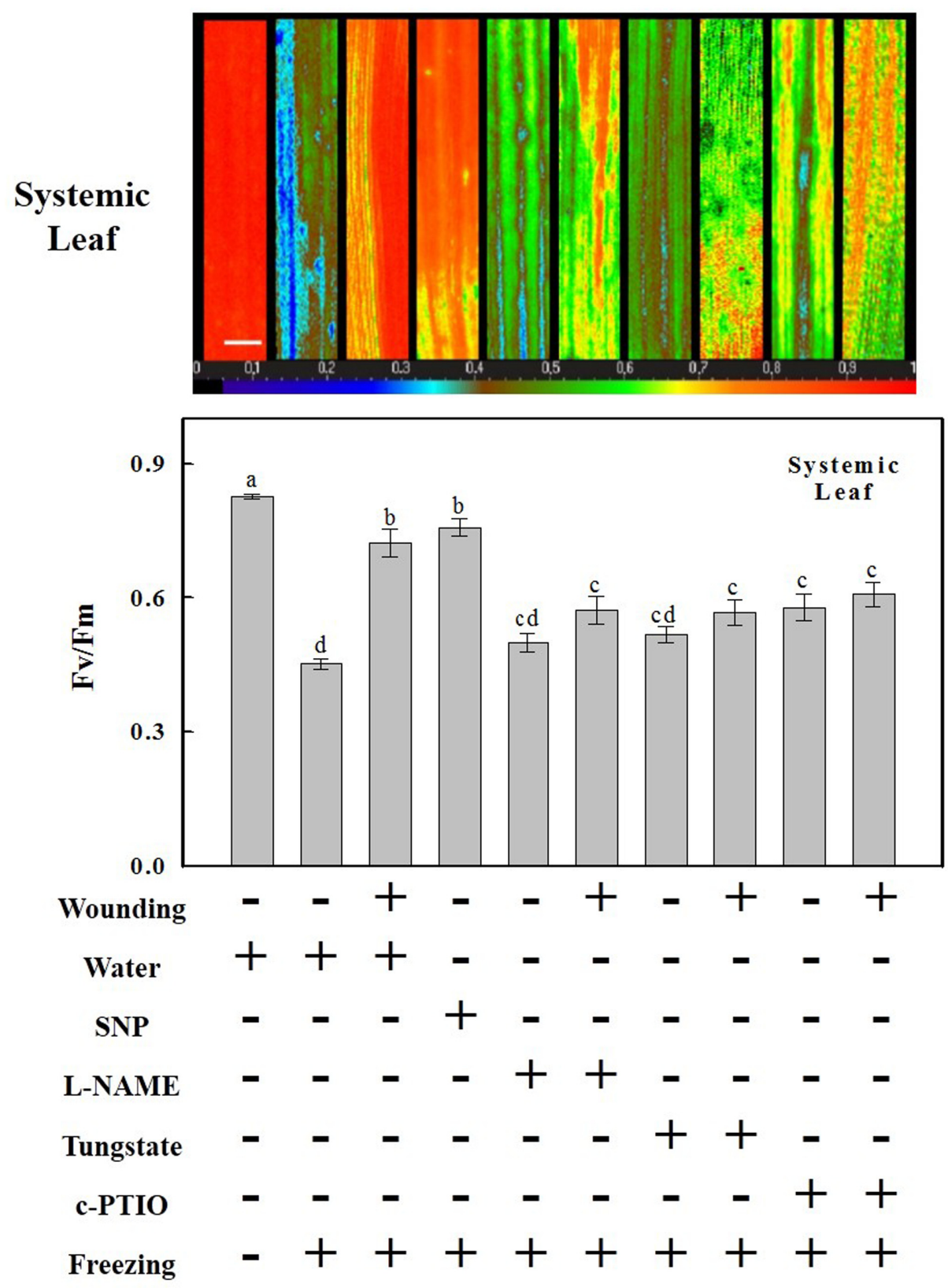

FIGURE 3 | The involvement of $\mathrm{NO}$ in the maintenance of FV/Fm of the system (fifth) leaf of cold stressed wheat plants by pre-wounding of the local (fourth) leaf. The systemic leaf was pre-treated with distilled water, $200 \mu \mathrm{M}$ SNP, $200 \mu \mathrm{M}$ L-NAME, $200 \mu \mathrm{M}$ tungstate or $200 \mu \mathrm{M}$ c-PTIO prior to wounded $8 \mathrm{~h}$ later. FV/Fm was then determined by the systemic leaf as area of interest after $24 \mathrm{~h}$ freezing stress and one representative is shown. The horizontal false color code ranges from 0.0 (black) to 1.0 (red). Bar, $10 \mathrm{~mm}$. Average values of $F \mathrm{v} / F \mathrm{~m}$ of systemic leaf by these treatments were also shown here. Data are means $\pm \mathrm{SD}$ of three different replicates. Means denoted by the same letter did not significantly differ at $P<0.05$ according to Tukey's test. 
To further characterize the role of $\mathrm{NO}$ in woundinginduced freezing tolerance, the effect of freezing-mediated oxidative stress applied at different intervals after SNP or wounding treatment was determined. Enhanced tolerance of the systemic leaves to freezing-induced oxidative stress was observed as early as $3 \mathrm{~h}$ after treatment with SNP and $6 \mathrm{~h}$ after mechanical wounding, suggesting that exogenous NO induced freezing tolerance more rapidly than wounding. As depicted in Supplementary Figure S1, the maximum level of freezing tolerance was observed at $6 \mathrm{~h}$ after treatment with SNP and at $12 \mathrm{~h}$ after mechanical wounding, respectively. No significant level of freezing tolerance was observed at $48 \mathrm{~h}$ after treatment with SNP. Nevertheless, the alleviation effect of mechanical wounding still existed during the remainder of the time course, only slightly declined compared to that of $12 \mathrm{~h}$ (Supplementary Figure S1).

We then determined the role of NO in the up-regulation of antioxidant defense systems after wounding or SNP treatment. Local mechanical wounding increased the activities of SOD, CAT, APX, and GR not only in local leaves but also in systemic leaves at $3 \mathrm{~h}$ in comparison with normally grown counterpart (Figure 4). The increased activities of these enzymes were effectively blocked by pre-treatments with L-NAME, tungstate or c-PTIO in both local and systemic leaves, suggesting that wounding-induced systemic tolerance is mediated by the signaling of NO. Analysis of the antioxidant-related gene expression showed that the SOD, $C A T, A P X$, and GR transcription levels coincide with their corresponding enzyme activities. In particular, the expression of

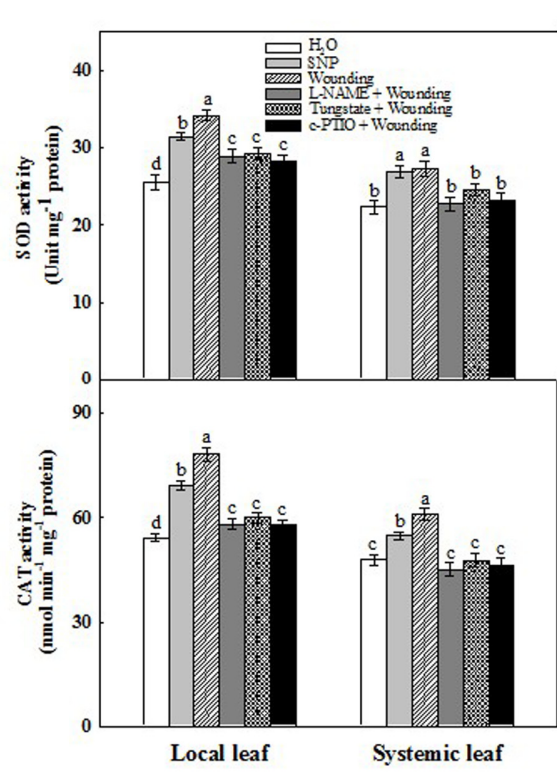

Local leaf
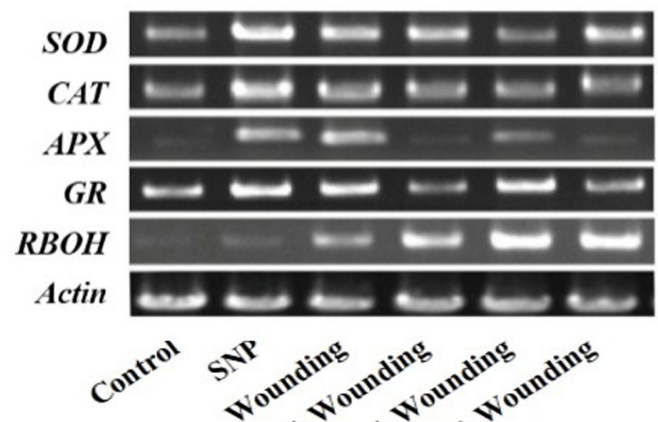

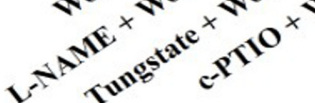

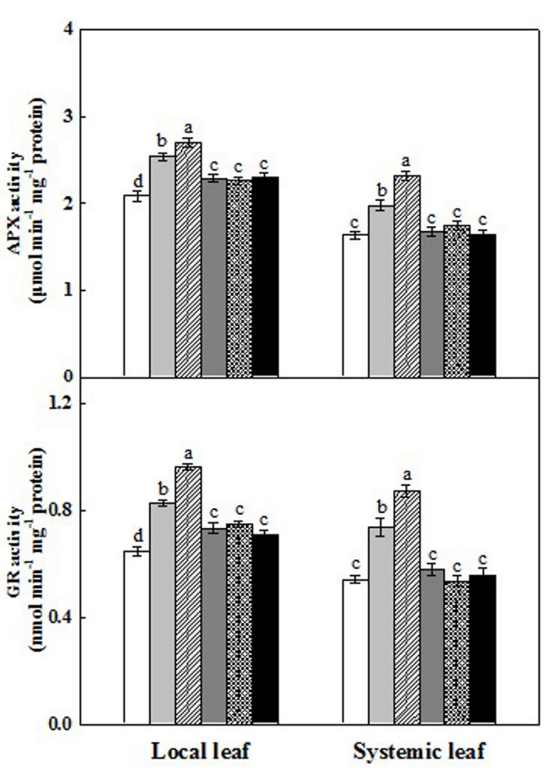

Systemic leaf
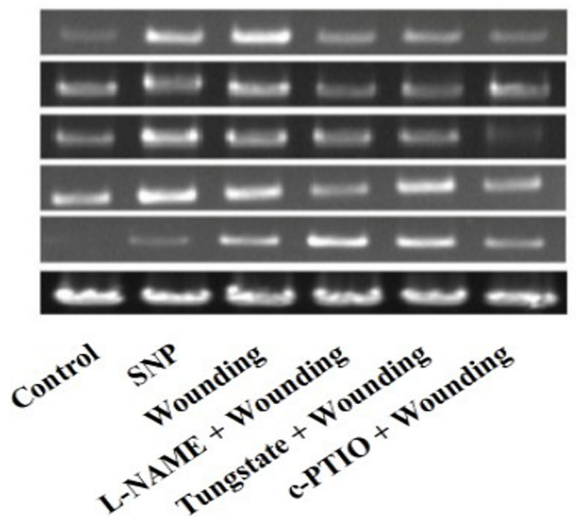

FIGURE 4 | Requirement of NO in wounding-induced activities of antioxidant enzymes and the expression of their corresponding genes as well as RBOH. The systemic (fifth) leaf was pre-treated with distilled water, $200 \mu \mathrm{M}$ SNP, $200 \mu \mathrm{M}$ L-NAME, $200 \mu \mathrm{M}$ tungstate or $200 \mu \mathrm{M}$ c-PTIO prior to mechanical wounding. The local and systemic leaves were harvested $3 \mathrm{~h}$ after wounding for analysis the activities of antioxidant enzymes and the expression levels. Data are means \pm SD of three different replicates. Means denoted by the same letter did not significantly differ at $P<0.05$ for each leaf according to Tukey's test. 
$\mathrm{RBOH}$ was profoundly higher in both local and systemic leaves after wounding, whilst NO donor as well as its inhibitors and scavenger had no significant effect on its expression (Figure 4). Collectively, we have clearly demonstrated that NO is involved in wounding-induced systemic freezing tolerance in wheat plants.

\section{Source of Endogenous $\mathrm{NO}$ and $\mathrm{H}_{2} \mathrm{O}_{2}$ in Response to Wounding}

To elaborate the possible source of wounding-induced early NO burst in wheat plants, we analyzed NR and NOS activities in both wounded local leaves and unwounded systemic leaves. Mechanical wounding substantially elevated NR activity in both local and systemic leaves at $3 \mathrm{~h}$, with 2.0 - and 1.6-fold increase as compared with the untreated plants, respectively. The NR activity was attenuated at $18 \mathrm{~h}$ but still maintained at high levels compared to unwounded plants (Figure 5A). In contrast, no significant difference in NOS activity was observed between wounded and unwounded plants at $3 \mathrm{~h}$ after wounding (Figure 5B). However, the NOS activity in local and systemic leaves of wounded plants was 1.2- and 1.1-fold higher than that

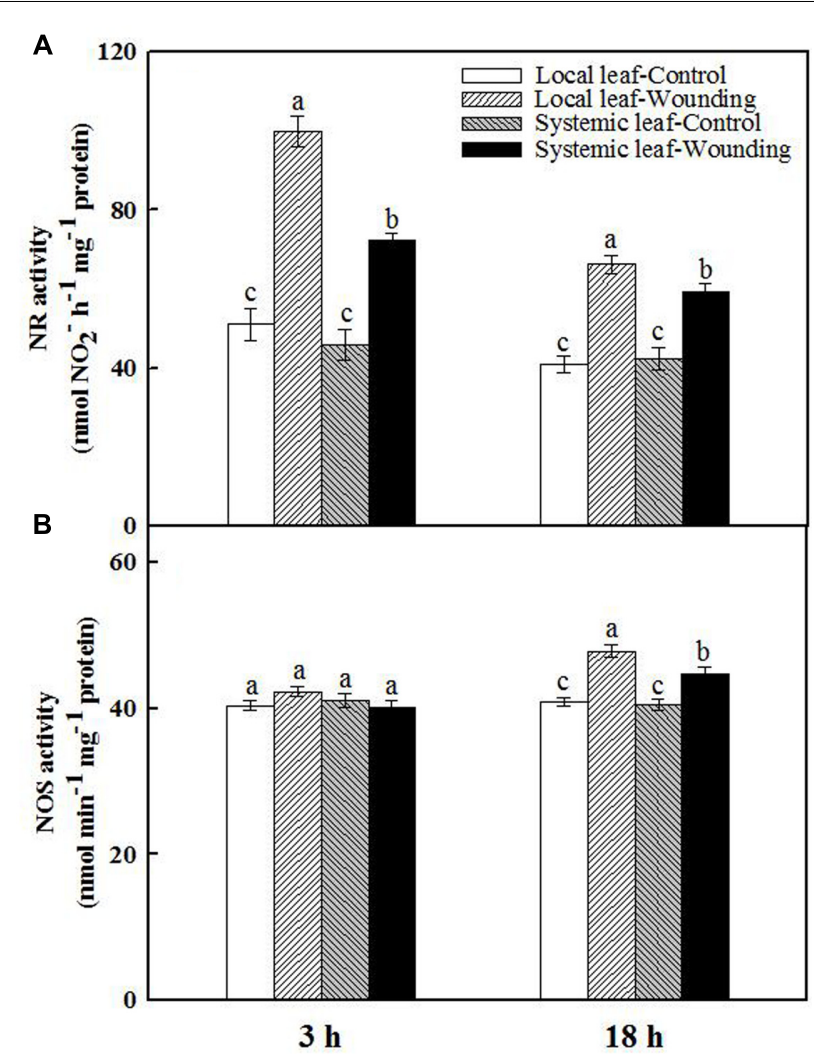

FIGURE 5 | Effect of mechanical wounding on activities of nitrate reductase (NR) (A) and nitric oxide synthase (NOS) (B) in local (fourth) and systemic (fifth) leaves. The local leaves were wounded and then both the local and systemic leaves were collected for analyzing the activities of NR and NOS at 3 and $18 \mathrm{~h}$ after wounding, respectively. Data are means \pm SD of three different replicates. Means denoted by the same letter did not significantly differ at $P<0.05$ for each leaf according to Tukey's test.

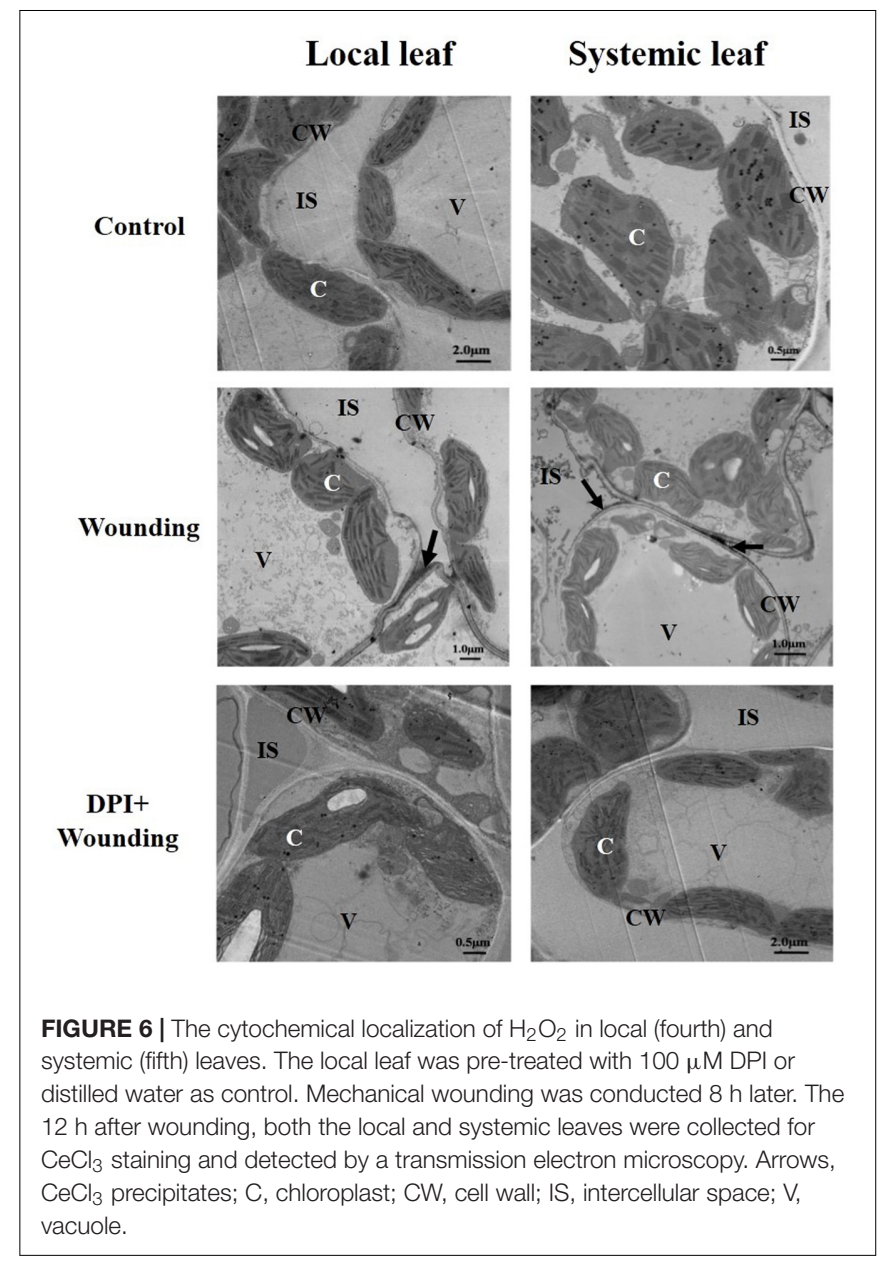

of controls at $18 \mathrm{~h}$ after wounding. These data imply that NR may mediate early NO burst while NOS is likely to act at a later phase in response to mechanical wounding.

To further confirm the origination of $\mathrm{H}_{2} \mathrm{O}_{2}$ caused by mechanical wounding, samples were detected at cytochemical level with $\mathrm{CeCl}_{3}$ staining. As depicted in Figure 6 and Supplementary Figure S2, $\mathrm{H}_{2} \mathrm{O}_{2}$ accumulation was predominantly distributed in the cell walls of local and systemic leaves but was only detected in chloroplasts of local leaf after $12 \mathrm{~h}$ mechanical wounding. In comparison, wounding-induced $\mathrm{H}_{2} \mathrm{O}_{2}$ accumulation was visible only in chloroplasts of local leaf in DPI(an inhibitor of plasma membrane NADPH oxidase) treated plants (Supplementary Figure S2) and no $\mathrm{CeCl}_{3}$ staining was observed in the apoplast systemically (Figure 6). These results highlight the potential role of plasma membrane $\mathrm{RBOH}$ in the wounding signal transduction.

\section{Time Course of Wounding-Induced NO and $\mathrm{H}_{2} \mathrm{O}_{2}$ Accumulation, Systemic Tolerance, and Activities of Antioxidant Enzymes}

To obtain insight into the inter-relationship between $\mathrm{NO}$ and $\mathrm{H}_{2} \mathrm{O}_{2}$, we also detected their local and systemic accumulation 
triggered by mechanical wounding. A highly transient increase of NO was observed after 30 min of mechanical wounding in local leaves, attained peak level at $3 \mathrm{~h}$ and remained elevated for at least $6 \mathrm{~h}$ (Figure 7B). The elevated NO content was also observed in systemic leaves at $50 \mathrm{~min}$ and remained significantly higher until returned to the resting level at $12 \mathrm{~h}$ after wounding treatment. Nevertheless, NO content was comparatively lower than that in local leaves (Figure 7A). The intercellular $\mathrm{H}_{2} \mathrm{O}_{2}$ displayed a continual increase as early as at $20 \mathrm{~min}$ in local leaves and at $30 \mathrm{~min}$ in systemic leaves (Figures 7C,D). $\mathrm{H}_{2} \mathrm{O}_{2}$ levels remained elevated for at least $48 \mathrm{~h}$ in both local and systemic leaves. After $72 \mathrm{~h}$, no significant changes in $\mathrm{H}_{2} \mathrm{O}_{2}$ content were observed throughout the remaining period of the experiment. The accumulation of $\mathrm{H}_{2} \mathrm{O}_{2}$ was about 20 min earlier than that of $\mathrm{NO}$ in both local and systemic leaves, whilst the duration of high level $\mathrm{H}_{2} \mathrm{O}_{2}$ was much longer than that of NO. Besides, there exists
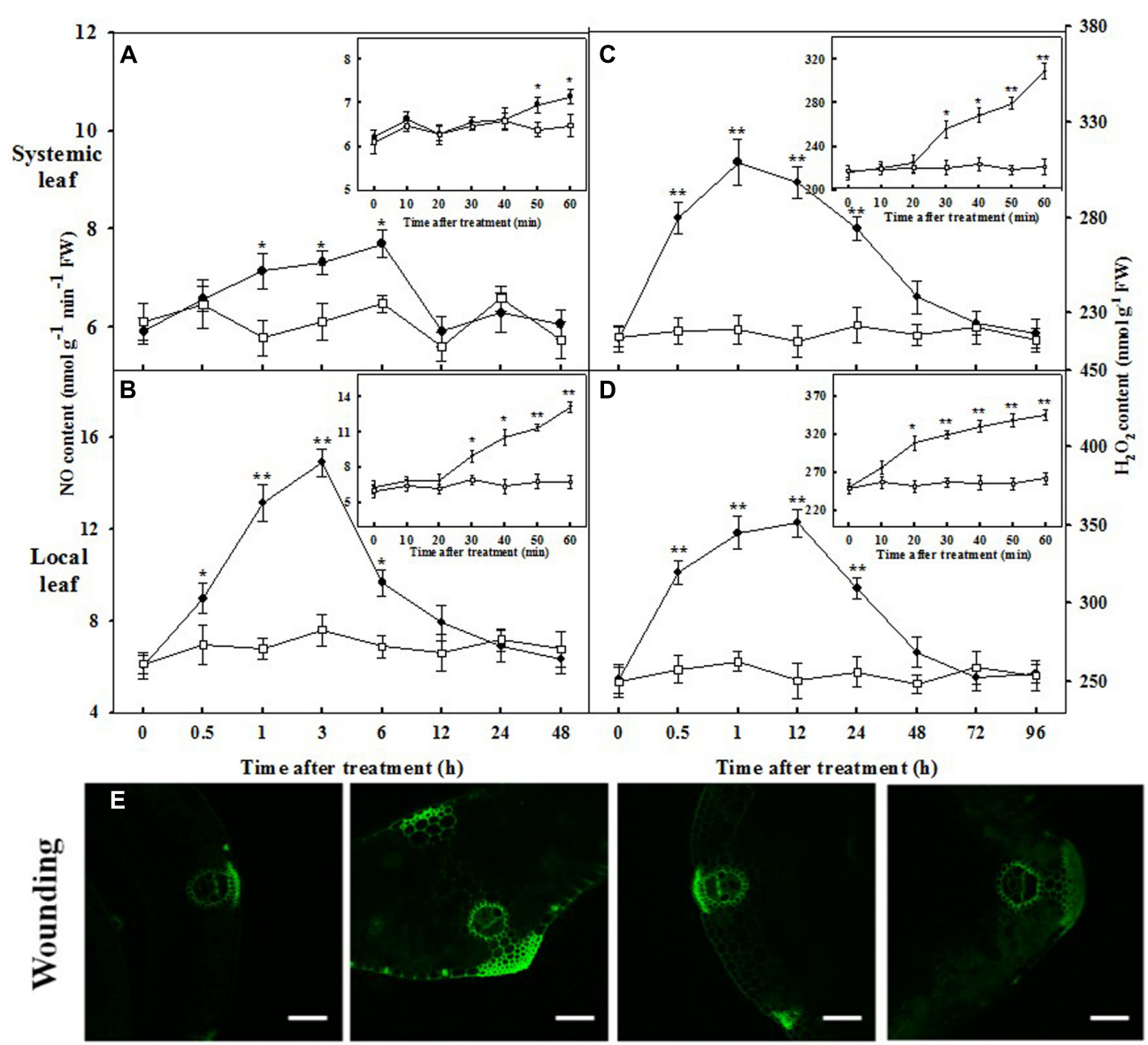

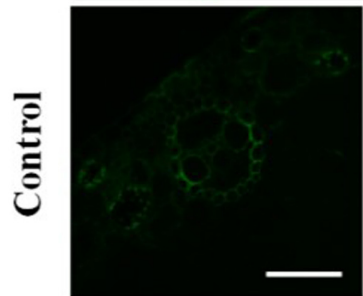

Sheath of local leaf

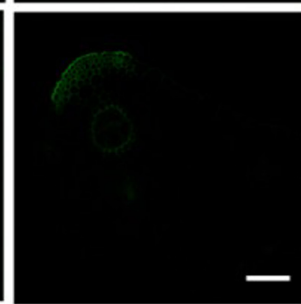

Local leaf

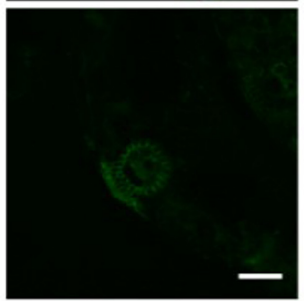

Sheath of systemic leaf

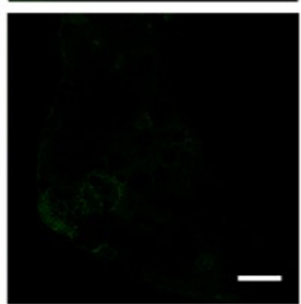

Systemic leaf

FIGURE 7 | Kinetics of changes in $\mathrm{NO}$ content, $\mathrm{H}_{2} \mathrm{O}_{2}$ content and imagines of $\mathrm{H}_{2} \mathrm{O}_{2}$ localization in the vascular tissues in response to mechanical wounding. The local (fourth) leaf was wounded and then harvested at indicated times after wounding treatment. $\mathrm{NO}$ and $\mathrm{H}_{2} \mathrm{O}_{2}$ content of the local or systemic leaf of wounded (circles) and untreated (squares) plants were assayed. Time zero points represent without wounding treatment. The top and bottom graphs represent the systemic and local leaves, respectively (A-D). Data are means \pm SD of three different replicates. Insets: the average \pm SE of two treatments in which the samples were harvested with an interval of 10 min for a better understanding of $\mathrm{NO}$ and $\mathrm{H}_{2} \mathrm{O}_{2}$ accumulation. Significance of variance for one-way ANOVA is indicated: $* P<0.05$; ${ }^{* *} P<0.01$. (E) The roots of the whole seedlings were incubated into H2DCF-DA over night. The local leaf was prior wounded, after which the leaves and stems were sliced $3 \mathrm{~h}$ later and detected by a CLSM (excitation, $480 \mathrm{~nm}$; emission, $530 \mathrm{~nm}$ ). Bars, $100 \mu \mathrm{m}$. 
a temporal overlap between wounding-induced $\mathrm{NO}$ and $\mathrm{H}_{2} \mathrm{O}_{2}$ from about $1 \mathrm{~h}$ to $6 \mathrm{~h}$ after wounding (Figure 7). To visually observe the signal transduction of $\mathrm{H}_{2} \mathrm{O}_{2}$, the vascular tissues were stained by H2DCF-DA fluorescent staining. Figure $7 \mathbf{E}$ shows that local mechanical wounding-induced $\mathrm{H}_{2} \mathrm{O}_{2}$ signal along the vascular tissue not only in local leaf and systemic leaf, but also in the sheaths of the leaves. The green fluorescent signals were significant in both leaf tissues and sheaths in wounded plants than their corresponding control.

The temporal changes in the activities of antioxidant enzymes were also investigated. In total, the activities of SOD, APX, and GR were increased concomitantly as early as at $3 \mathrm{~h}$ after mechanical wounding in both local and systemic leaves, whereas CAT activity was markedly elevated at $6 \mathrm{~h}$ in response to mechanical wounding (Supplementary Figure S3). The activities of all these antioxidant enzymes were peaked at $6 \mathrm{~h}$ in local leaves and at $12 \mathrm{~h}$ in systemic leaves. The elevated activities of these enzymes were persisted for about 1 to 2 days before declining to control levels after mechanical wounding. Moreover, the decline of these antioxidant activities was accompanied by the disappearance of the photosynthetic protection induced by mechanical wounding. These findings highlight the dominant roles of $\mathrm{NO}$ and $\mathrm{H}_{2} \mathrm{O}_{2}$ interrelating with the signaling responses to wounding and freezing.

\section{Identification and Expression Patterns of Freezing or/and Wounding-Induced Genes}

To elucidate the molecular mechanisms underlying the wounding-mediated freezing tolerance in wheat, RNA-Seq assay was performed for systemic leaves after the following treatment: untreated (ck), wounding treatment for $3 \mathrm{~h}$ (wo), freezing treatment for $24 \mathrm{~h}$ (fr), and wounding for $3 \mathrm{~h}$ plus freezing treatment for $24 \mathrm{~h}$ (wo_fr). A total of 9018 different expressed genes (DE-genes) were detected compared with control leaves. Among them, 1062 genes were identified in the data from all three treatments, and specifically 514 were up-regulated while 368 were down-regulated in all three treatments (Figure 8A and Supplementary Figure S4). Comparing the up-regulated genes between freezing treatment and wounding/freezing treatment, 3237 genes were overlapped. However, 279 genes were only significantly up-regulated in the plants treatment with wounding and freezing, but not in the plants treated with freezing only, which implies that these 279 genes may contribute to woundinginduced freezing tolerance (Figure 8A). Among these 279 genes, 33 were involved in the categories "Photosynthesis" while eight genes were significantly increased in "ROS" (Supplementary Table S2).

In order to further understand the functions of wounding and freezing regulated genes, Gene Ontology (GO) enrichment analysis was performed for the 4264 differentially expressed genes after wounding and freezing treatment. Wounding and freezing regulated genes were significantly enriched in the categories "photosynthesis," "generation of precursor metabolites and energy," "photosynthesis, light reaction," "signal transmission," "signaling process," "photosynthesis, light harvesting," "signal transduction," “signaling," etc. (Figure 8B). Similarly, the differentially expressed genes in wounding plants were also enriched in "photosynthesis, light harvesting," "photosynthesis," etc. (Supplementary Figure S5B). In contrast, the differentially expressed genes in freezing plants were enriched in "signaling process," "signal transmission," etc., but not in "photosynthesis" (Supplementary Figure S5A). Altogether, the transcriptional profile supports our experimental data showing that pretreatment with wounding increases photosynthesis efficiency and ROS level of wheat under cold condition.

\section{DISCUSSION}

Over the years, a number of research groups have committed to reveal the alleviation effects of low temperature stress on plants at physiological and molecular levels (Li et al., 2013; Dong et al., 2014; Zhang et al., 2016). SAA, which is proposed as an effective method in response to various abiotic stresses, has been widely investigated (Capiati et al., 2006; Zhou et al., 2014; Mittler and Blumwald, 2015). In the present study, we have well demonstrated that mild mechanical wounding in local leaves is capable of enhancing subsequent freezing tolerance in systemic leaves of wheat plants. Local wounding treatment enhanced tolerance to freezing-induced photooxidative stress, considerably increased Pn and Fv/Fm (Figure 1), coupled with strengthened antioxidant system (Figure $\mathbf{4}$ and Supplementary Figure S3) in untreated systemic leaves and ultimately alleviated freezing stress. Our research may contribute to develop novel management to mitigate the impact of low temperature stress and minimize the economic losses due to global climate change in wheat production.

\section{The Relationship between Wounding-Induced $\mathrm{NO}$ and $\mathrm{H}_{2} \mathrm{O}_{2}$}

Systemic signaling has been demonstrated to play important roles in the process of SAA. It is well established that both $\mathrm{NO}$ and $\mathrm{H}_{2} \mathrm{O}_{2}$ take an active part in the signal cascade in response to mechanical wounding (Orozco-Cárdenas et al., 2001; Jih et al., 2003; Schilmiller and Howe, 2005; Arasimowicz et al., 2009). Wounding-induced $\mathrm{H}_{2} \mathrm{O}_{2}$ activated the expression of the defense-related gene IPO in sweet potato, identical to the inhibitor of $\mathrm{NO}$, validating the antagonistic roles between $\mathrm{NO}$ and $\mathrm{H}_{2} \mathrm{O}_{2}$ in regulating wounding-induced defense system (Jih et al., 2003). However, a different picture emerged that NO donor acutely decreased $\mathrm{H}_{2} \mathrm{O}_{2}$ content after wounding in sweet potato, implying that $\mathrm{NO}$ acts in concert with $\mathrm{H}_{2} \mathrm{O}_{2}$ in response to mechanical wounding (Lin et al., 2011). The discrepancy between these studies implies that some unknown signaling pathways have yet to be elucidated. Therefore, the question of the relationship between $\mathrm{H}_{2} \mathrm{O}_{2}$ accumulation and $\mathrm{NO}$ production in wheat plants exposed to mechanical wounding appears to be particularly interesting.

In this paper, three lines of evidence illustrate that $\mathrm{H}_{2} \mathrm{O}_{2}$ acts upstream of $\mathrm{NO}$ in the wounding-induced antioxidant defense. First, the time-course analysis of $\mathrm{H}_{2} \mathrm{O}_{2}$ accumulation and $\mathrm{NO}$ production revealed that the generation of $\mathrm{H}_{2} \mathrm{O}_{2}$ preceded the 


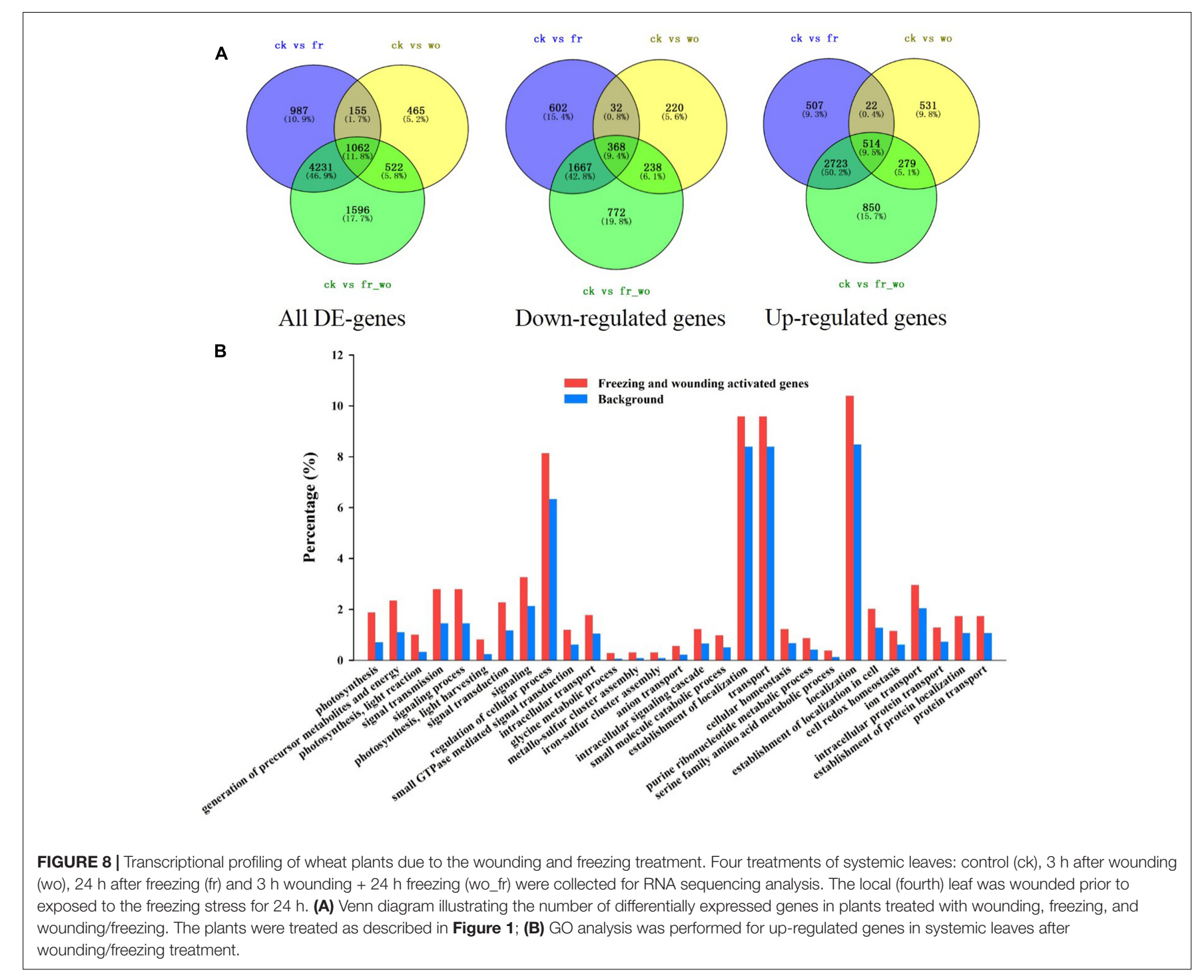

production of NO in the wounding signal in both local and systemic leaves (Figure 7). Second, wounding-induced NO burst was nearly fully inhibited by pretreatment with $\mathrm{H}_{2} \mathrm{O}_{2}$ inhibitors or scavenger (Figure 2), suggesting that $\mathrm{NO}$ synthesis might be the result of $\mathrm{H}_{2} \mathrm{O}_{2}$ accumulation. Third, pretreatment with $\mathrm{NO}$ inhibitors and scavenger had little effects on wounding-induced $\mathrm{H}_{2} \mathrm{O}_{2}$ generation, indicating that $\mathrm{NO}$ synthesis is not required for the initial $\mathrm{H}_{2} \mathrm{O}_{2}$ accumulation (Figure 2). Taken together, our data suggest that wounding-induced $\mathrm{H}_{2} \mathrm{O}_{2}$ activates the systemic production of $\mathrm{NO}$ and eventually strengthened the antioxidant defense systems in wheat plants.

\section{Systemic Signal Transduction between $\mathrm{NO}$ and $\mathrm{H}_{2} \mathrm{O}_{2}$ in Response to Wounding}

Evidences hints that NO is a short term signal which do not transport in long-distance in plant tissues (París et al., 2007; Mai et al., 2014). Instead, S-nitrosoglutathione (GSNO), formed by efficiently binding of NO to glutathione, has been proposed as a systemic wounding signal (Rustérucci et al., 2007; Espunya et al., 2012). As a relatively active molecule, however, $\mathrm{H}_{2} \mathrm{O}_{2}$ could migrate from the synthetic site to the neighboring vascular tissues or leaves (Buchanan and Balmer, 2005; Gilroy et al., 2014). Importantly, the systemic accumulation of $\mathrm{H}_{2} \mathrm{O}_{2}$ plays crucial roles in ameliorating various biotic and abiotic stimuli (Fryer et al., 2003; Bienert et al., 2006; Xia et al., 2011; Mignolet-Spruyt et al., 2016). In agreement with these findings, we observed that treatment with inhibitors and scavenger of $\mathrm{NO}$ in local leaves remarkably abolished wounding-induced $\mathrm{NO}$ accumulation in local leaves but had no influence on that in systemic leaves (Figures 2A,D). On the contrary, the inhibitor and scavenger of $\mathrm{H}_{2} \mathrm{O}_{2}$ sharply reduced $\mathrm{H}_{2} \mathrm{O}_{2}$ accumulation and $\mathrm{O}_{2}^{-} \bullet$ production rate in both local and systemic leaves (Figures $2 \mathrm{~B}-\mathrm{D}$ ), raising the possibility that the accumulation of $\mathrm{H}_{2} \mathrm{O}_{2}$ in systemic leaves seem to result from local leaves along the path of the systemic signals while the systemic production of NO could be originated from $\mathrm{H}_{2} \mathrm{O}_{2}$ (Figure 7). Thus, it is necessary to investigate the possible source of $\mathrm{H}_{2} \mathrm{O}_{2}$ and $\mathrm{NO}$ in response to mechanical wounding. 
Accumulating evidence postulated that wounding-induced $\mathrm{RBOH}$ is responsible for $\mathrm{H}_{2} \mathrm{O}_{2}$ accumulation (Sagi et al., 2004; Miller et al., 2009; Suzuki et al., 2012). In this work, when treatment of the local leaves with the $\mathrm{RBOH}$ inhibitor DPI or $\mathrm{H}_{2} \mathrm{O}_{2}$ scavenger DMTU prior to mechanical wounding, the concentration of $\mathrm{H}_{2} \mathrm{O}_{2}$ was dramatically decreased (Figures 2B,D). At subcellular level, DPI only scavenged the accumulation of $\mathrm{H}_{2} \mathrm{O}_{2}$ in the apoplast facing intercellular spaces but not those in chloroplasts (Figure 6 and Supplementary Figure S1). Apparently, plasma membrane $\mathrm{RBOH}$ is the major but not the only source of $\mathrm{H}_{2} \mathrm{O}_{2}$ in response to mechanical wounding. There are hints suggesting that $\mathrm{RBOH}$ mediating $\mathrm{H}_{2} \mathrm{O}_{2}$ has also been demonstrated as the long-distance signal from stimulated parts to the whole plants in response to various abiotic stresses (Neill et al., 2002; Mittler et al., 2004, 2011). In agreement with these findings, $\mathrm{H}_{2} \mathrm{O}_{2}$ accumulation was only detected in the apoplast of the systemic leaf after wounding but not in chloroplasts (Figure 6 and Supplementary Figure S2). To this regard, we confirm that $\mathrm{RBOH}$ in plasma membrane contribute to the rapid production of systemic $\mathrm{H}_{2} \mathrm{O}_{2}$ in the wounding signal cascade. NR and NOS have been implicated as two major enzymes responsible for $\mathrm{NO}$ biosynthesis in plants (Rockel et al., 2002; Besson-Bard et al., 2008; Corpas et al., 2008; Chaki et al., 2011). The possible source of the early burst NO involved in mechanical wounding was also detected and quantified in this paper by in situ and hemoglobin assay, respectively. NR inhibitor tungstate greatly abolished woundinginduced NO accumulation, a slight lower compared to that of L-NAME, a NOS inhibitor (Figures 2A,D). The activities of NR and NOS were further analyzed at 3 and $18 \mathrm{~h}$ after mechanical wounding as previously discussed (Figure 5), resulting in a conclusion that NR is the major source of early NO accumulation on local leaves in response to mechanical wounding.

\section{Crosstalk between $\mathrm{H}_{2} \mathrm{O}_{2}$ and $\mathrm{NO}$ in Wounding-Induced Freezing Tolerance}

It has been repeatedly reported that both $\mathrm{H}_{2} \mathrm{O}_{2}$ and $\mathrm{NO}$ act as second messengers in perception and transduction of signals in alleviating low temperature stress (Prasad et al., 1994; Suzuki and Mittler, 2006; Esim and Atici, 2014). NO evoked by NR during cold acclimation alleviated the following freezing stress in Arabidopsis (Zhao et al., 2009); Coincidentally, $\mathrm{H}_{2} \mathrm{O}_{2}$ generated by $\mathrm{RBOH}$ played a vital role in cold acclimation-induced chilling tolerance (Zhou et al., 2012). Based on the previous results, we believe that the $\mathrm{H}_{2} \mathrm{O}_{2}$ and $\mathrm{NO}$ induced by mechanical wounding might contribute to the subsequent freezing tolerance. Thus, a hypothesis has been put forward that local mechanical woundinginduced $\mathrm{H}_{2} \mathrm{O}_{2}$ and $\mathrm{NO}$ in local leaves, triggered the systemic signals along the pathway, and subsequently regenerated $\mathrm{H}_{2} \mathrm{O}_{2}$ together with NO in systemic leaves, which in turn lead to the up-regulation of antioxidant defense systems in wheat plants. Our results revealed the distinctive roles of mechanical wounding in strengthening freezing tolerance via the process of $\mathrm{H}_{2} \mathrm{O}_{2}$ and $\mathrm{NO}$ accumulation. We first observed that $\mathrm{NO}$ was accumulated not only in wounded local leaves, but also in untreated systemic leaves of wheat plants (Figure 7). Pretreatment of the NO synthetic inhibitors L-NAME and tungstate or NO scavenger c-PTIO substantially down-regulated the activities of antioxidant enzymes and consequently reduced tolerance to freezing stress in systemic leaves (Figures 3, 4). Additionally, the strengthened antioxidant system in response to mechanical wounding were consistent with the temporal changes of wounding-induced $\mathrm{H}_{2} \mathrm{O}_{2}$ in both local leaves and systemic leaves (Supplementary Figure S3). Besides, the protection mechanism of mechanical wounding on photosystem sustained for at least 3 days compared to that of SNP pretreatment (Supplementary Figure S1). One potential explanation cannot be discarded because that other signal molecules or phytohormones instead of $\mathrm{H}_{2} \mathrm{O}_{2}$ and $\mathrm{NO}$ are involved in the resistance of freezing stress such as ABA, salicylic acid, jasmonic acid, and polyamines (Shen et al., 2000; Dong et al., 2014; Wang et al., 2016) which have yet to be fully elucidated in future studies. Taken together, the sustained freezing tolerance in wounded plants is likely to be mediated by the systemic accumulation of $\mathrm{NO}$ in a $\mathrm{H}_{2} \mathrm{O}_{2}$ dependent manner, namely, $\mathrm{H}_{2} \mathrm{O}_{2}$ and $\mathrm{NO}$ act sequentially and synergistically in the early phase of this cross-tolerance signaling network.

\section{Wounding-Induced Freezing Tolerance by Enhancing Antioxidant System and Photosystem via ROS Signal}

Under freezing conditions, ROS may play two different roles: exacerbating the damage, or signaling the activation of defense responses (Baxter et al., 2014). Here, the accumulated $\mathrm{H}_{2} \mathrm{O}_{2}$ in systemic leaves after mechanical wounding could play positive roles in freezing tolerance other than causing oxidation of cellular components. Although the concentration of $\mathrm{H}_{2} \mathrm{O}_{2}$ in systemic leaves was increased upon wounding (Figure 7C), the activities of antioxidant enzymes were increased as well, which may contribute to alleviating oxidative stress (Supplementary Figure S3). On the other hand, the decreased REC and MDA content were also observed (Figure 1B), thus validating the regulatory role of $\mathrm{H}_{2} \mathrm{O}_{2}$ in antioxidant system in woundinginduced freezing tolerance.

Literatures indicate that wounding indirectly suppressed photosynthesis of remaining undamaged leaves (Zangerl et al., 2002; Aldea et al., 2005; Nabity et al., 2009). In this paper, however, the ameliorating effects of mechanical wounding on photosystem under freezing stress were observed at both physiological and transcriptional levels, thus validating the dual role of mechanical wounding on photosystem. The strong arguments between the previous studies and ours may due to three main reasons. First, in stances they use arthropod herbivory as wounding treatment tools while we use hemostat which may results in different kinds of initiations of wounding signal. Second, we use wheat, a kind of monocotyledon as plant material in which the vascular tissues are unique from those in dicotyledons. The systemic tissues analyzed in previous studies were connected to wounded leaves or even in the same leaf. In our study, however, the wounding signal ROS were detected in sheaths of both local and systemic leaves (Figure 7E), indicating a more complicated signal 


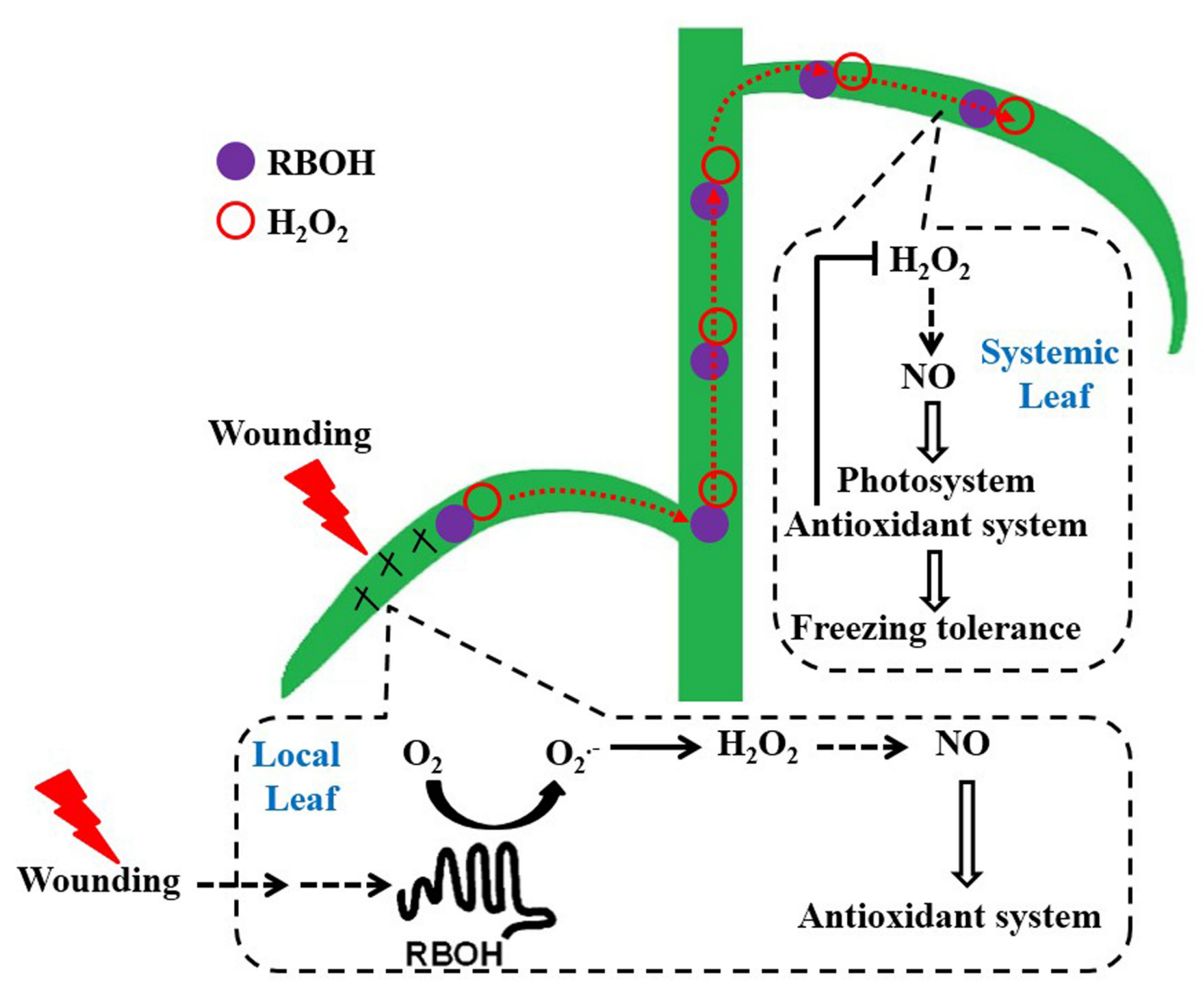

FIGURE 9 | The working model illustrating the induction of freezing tolerance by mechanical wounding in wheat plant. Perception of wounding signal in local leaf results in the accumulation of $\mathrm{H}_{2} \mathrm{O}_{2}$ systemically (resulted from the plasma membrane-bound NADPH oxidase). Elevated levels of $\mathrm{H}_{2} \mathrm{O}_{2}$ triggers and amplifies the signaling pathway of wounding and then induces $\mathrm{NO}$ in a NR-dependent manner in systemic leaf. NO further functions as a signal molecule to up-regulate the photosystem and antioxidant system in response to freezing stress.

transduction mechanism in monocotyledons. Third, previous reporters focused on the systemic changes of photosystem after wounding treatment alone, whereas we not only interpreted the essential of wounding signal, but also shed light on the alleviation effects of mechanical wounding on freezing stress. At first glance, wounding suppressed photosynthesis of systemic leaves, however, the reinforcement of photosystem was emerged after exposed to freezing stress. The potential explanation of this phenomenon is that wounding-induced systemic ROS signal enhanced the photosystem thus contributed to the acquisition of freezing tolerance (Figures 1, 3, 4, 8).

\section{CONCLUSION}

We have presented strong physiological, biochemical, and transcriptional experiments that local mechanical wounding induces early $\mathrm{NO}$ burst through a NR route in a $\mathrm{H}_{2} \mathrm{O}_{2}$-dependent manner (mediated by plasma membrane $\mathrm{RBOH}$ ). Then, $\mathrm{H}_{2} \mathrm{O}_{2}$ triggers and amplifies the signaling pathway of wounding to systemic leaves within minutes and reproduced $\mathrm{NO}$ for signaling purpose. $\mathrm{H}_{2} \mathrm{O}_{2}$ and $\mathrm{NO}$ then act in concert and ultimately strengthen the photosystem as well as the antioxidant defense system to alleviate oxidative states arising from freezing stress in systemic leaves (Figure 9). To the best of our knowledge, it was the first time to reveal this new type of SAA, i.e., alleviation effects of mechanical wounding on freezing tolerance in wheat. Additional work using proteomic and molecular approaches are required to understand the detailed mechanism of woundinginduced freezing tolerance.

\section{AUTHOR CONTRIBUTIONS}

TS and DJ conceived and designed the experiments; TS, XW, LW, LZ, MH, JC, QZ, and TD performed the experiments; TS, J-KZ, and CZ analyzed the RNA-seq data; TS and DJ wrote the article with contribution of all the authors.

\section{ACKNOWLEDGMENTS}

This study is supported by the National Natural Science Foundation of China (31325020, 31401326, 31471445), the China 
Agriculture Research System (CARS-03), Jiangsu Collaborative Innovation Center for Modern Crop Production (JCIC-MCP), Collaborative Innovation Center of Gene Resources, and the National Non-profit Program by Ministry of Agriculture (2014039).

\section{REFERENCES}

Ahuja, I., de Vos, R. C., Bones, A. M., and Hall, R. D. (2010). Plant molecular stress responses face climate change. Trends Plant Sci. 15, 664-674. doi: 10.1016/j. tplants.2010.08.002

Aldea, M., Hamilton, J. G., Resti, J. P., Zangerl, A. R., Berenbaum, M. R., and D Elucia, E. H. (2005). Indirect effects of insect herbivory on leaf gas exchange in soybean. Plant Cell Environ. 28, 402-411. doi: 10.1111/j.1365-3040.2005. 01279.x

Alvarez, M. A. E., Pennell, R. I., Meijer, P.-J., Ishikawa, A., Dixon, R. A., and Lamb, C. (1998). Reactive oxygen intermediates mediate a systemic signal network in the establishment of plant immunity. Cell 92, 773-784. doi: 10.1016/ S0092-8674(00)81405-1

Arasimowicz, M., Floryszak-Wieczorek, J., Milczarek, G., and Jelonek, T. (2009). Nitric oxide, induced by wounding, mediates redox regulation in pelargonium leaves. Plant Biol. 11, 650-663. doi: 10.1111/j.1438-8677.2008.00164.x

Asseng, S., Foster, I. A. N., and Turner, N. C. (2011). The impact of temperature variability on wheat yields. Glob. Chang. Biol. 17, 997-1012. doi: 10.1111/j.13652486.2010.02262.x

Baxter, A., Mittler, R., and Suzuki, N. (2014). ROS as key players in plant stress signalling. J. Exp. Bot. 65, 1229-1240. doi: 10.1093/jxb/ert375

Besson-Bard, A., Pugin, A., and Wendehenne, D. (2008). New insights into nitric oxide signaling in plants. Annu. Rev. Plant Biol. 59, 21-39. doi: 10.1146/ annurev.arplant.59.032607.092830

Bestwick, C. S., Brown, I. R., Bennett, M. H., and Mansfield, J. W. (1997). Localization of hydrogen peroxide accumulation during the hypersensitive reaction of lettuce cells to Pseudomonas syringae pv phaseolicola. Plant Cell 9, 209-221. doi: 10.1105/tpc.9.2.209

Bienert, G. P., Schjoerring, J. K., and Jahn, T. P. (2006). Membrane transport of hydrogen peroxide. Biochim. Biophys. Acta 1758, 994-1003. doi: 10.1016/j. bbamem.2006.02.015

Bradford, M. M. (1976). Rapid and sensitive method for quantitation of microgram quantities of protein utilizing principle of protein-dye binding. Anal. Biochem. 72, 248-254. doi: 10.1016/0003-2697(76)90527-3

Bright, J., Desikan, R., Hancock, J. T., Weir, I. S., and Neill, S. J. (2006). ABAinduced NO generation and stomatal closure in Arabidopsis are dependent on $\mathrm{H}_{2} \mathrm{O}_{2}$ synthesis. Plant J. 45, 113-122. doi: 10.1111/j.1365-313X.2005.02615.x

Buchanan, B. B., and Balmer, Y. (2005). Redox regulation: a broadening horizon. Annu. Rev. Plant Biol. 56, 187-200. doi: 10.1146/annurev.arplant.56.032604. 144246

Capiati, D. A., País, S. M., and Téllez-Iñón, M. T. (2006). Wounding increases salt tolerance in tomato plants: evidence on the participation of calmodulinlike activities in cross-tolerance signalling. J. Exp. Bot. 57, 2391-2400. doi: $10.1093 /$ jxb/erj212

Chaki, M., Valderrama, R., Fernández-Ocaña, A. M., Carreras, A., GómezRodríguez, M. V., Pedrajas, J. R., et al. (2011). Mechanical wounding induces a nitrosative stress by down-regulation of GSNO reductase and an increase in S-nitrosothiols in sunflower (Helianthus annuus) seedlings. J. Exp. Bot. 62, 1803-1813. doi: 10.1093/jxb/erq358

Chinnusamy, V., Zhu, J., and Zhu, J.-K. (2007). Cold stress regulation of gene expression in plants. Trends Plant Sci. 12, 444-451. doi: 10.1016/j.tplants.2007. 07.002

Corpas, F. J., Chaki, M., Fernández-Ocaña, A., Valderrama, R., Palma, J. M., Carreras, A., et al. (2008). Metabolism of reactive nitrogen species in pea plants under abiotic stress conditions. Plant Cell Physiol. 49, 1711-1722. doi: 10.1093/ pcp/pcn 144

Dong, C. J., Li, L., Shang, Q. M., Liu, X. Y., and Zhang, Z. G. (2014). Endogenous salicylic acid accumulation is required for chilling tolerance in cucumber (Cucumis sativus L.) seedlings. Planta 240, 687-700. doi: 10.1007/s00425-0142115-1

\section{SUPPLEMENTARY MATERIAL}

The Supplementary Material for this article can be found online at: http://journal.frontiersin.org/article/10.3389/fpls.2017.01284/ full\#supplementary-material

Elstner, E., and Heupel, A. (1976). Inhibition of nitrite formation from hydroxylammoniumchloride: a simple assay for superoxide dismutase. Anal. Biochem. 70, 616-620. doi: 10.1016/0003-2697(76)90488-7

Esim, N., and Atici, O. (2014). Nitric oxide improves chilling tolerance of maize by affecting apoplastic antioxidative enzymes in leaves. Plant Growth Regul. 72, 29-38. doi: 10.1007/s10725-013-9833-4

Espunya, M. C., De Michele, R., Gómez-Cadenas, A., and Martínez, M. C. (2012). S-Nitrosoglutathione is a component of wound- and salicylic acidinduced systemic responses in Arabidopsis thaliana. J. Exp. Bot. 63, 3219-3227. doi: 10.1093/jxb/ers043

Evans, M. J., Choi, W.-G., Gilroy, S., and Morris, R. J. (2016). A ROS-assisted calcium wave dependent on the AtRBOHD NADPH oxidase and TPC1 cation channel propagates the systemic response to salt stress. Plant Physiol. 171, 1771-1784. doi: 10.1104/pp.16.00215

Foyer, C. H., and Halliwell, B. (1976). The presence of glutathione and glutathione reductase in chloroplasts: a proposed role in ascorbic acid metabolism. Planta 133, 21-25. doi: 10.1007/BF00386001

Fryer, M. J., Ball, L., Oxborough, K., Karpinski, S., Mullineaux, P. M., and Baker, N. R. (2003). Control of Ascorbate Peroxidase 2 expression by hydrogen peroxide and leaf water status during excess light stress reveals a functional organisation of Arabidopsis leaves. Plant J. 33, 691-705. doi: 10.1046/j.1365313X.2003.01656.x

Gaupels, F., Furch, A. C. U., Zimmermann, M. R., Chen, F., Kaever, V., Buhtz, A., et al. (2016). Systemic induction of NO-, Redox-, and cGMP signaling in the pumpkin extrafascicular phloem upon local leaf wounding. Front. Plant Sci. 7:154. doi: 10.3389/fpls.2016.00154

Gilroy, S., Białasek, M., Suzuki, N., Górecka, M., Devireddy, A. R., Karpiński, S., et al. (2016). ROS, calcium, and electric signals: key mediators of rapid systemic signaling in plants. Plant Physiol. 171, 1606-1615. doi: 10.1104/pp.16. 00434

Gilroy, S., Suzuki, N., Miller, G., Choi, W.-G., Toyota, M., Devireddy, A. R., et al. (2014). A tidal wave of signals: calcium and ROS at the forefront of rapid systemic signaling. Trends Plant Sci. 19, 623-630. doi: 10.1016/j.tplants.2014. 06.013

González, A., Cabrera, M. D. L., Henríquez, M. J., Contreras, R. A., Morales, B., and Moenne, A. (2012). Cross talk among calcium, hydrogen peroxide, and nitric oxide and activation of gene expression involving calmodulins and calciumdependent protein kinases in Ulva compressa exposed to copper excess. Plant Physiol. 158, 1451-1462. doi: 10.1104/pp.111.191759

Griffith, M., and Mclntyre, H. C. H. (1993). The interrelationship of growth and frost tolerance in winter rye. Physiol. Plant. 87, 335-344. doi: 10.1111/j.13993054.1993.tb01739.x

Han, Q. X., Kang, G. Z., and Guo, T. C. (2013). Proteomic analysis of spring freezestress responsive proteins in leaves of bread wheat (Triticum aestivum L.). Plant Physiol. Biochem. 63, 236-244. doi: 10.1016/j.plaphy.2012.12.002

Hodges, D. M., Delong, J. M., Forney, C. F., and Prange, R. K. (1999). Improving the thiobarbituric acid-reactive-substances assay for estimating lipid peroxidation in plant tissues containing anthocyanin and other interfering compounds. Planta 207, 604-611. doi: 10.1007/s00425-017-2699-3

IPCC (2007). "Climate change 2007: the physical science basis," in Proceedings of the Contribution of Working Group I to the Fourth Assessment Report of the Intergovernmental Panel on Climate Change, eds S. Solomon, D. Qin, M. Manning, Z. Chen, M. Marquis, K. B. Averyt, et al. (Cambridge: Cambridge University Press).

Jabs, T., Dietrich, R. A., and Dangl, J. L. (1996). Initiation of runway cell death in an Arabidopsis mutant by extracellular superoxide. Science 27, 1853-1856. doi: $10.1126 /$ science.273.5283.1853

Jih, P.-J., Chen, Y.-C., and Jeng, S.-T. (2003). Involvement of hydrogen peroxide and nitric oxide in expression of the Ipomoelin Gene from sweet potato. Plant Physiol. 132, 381-389. doi: 10.1104/pp.102.015701 
Jin, C., Du, S., Shamsi, I. H., Luo, B., and Lin, X. (2011). NO synthase-generated NO acts downstream of auxin in regulating Fe-deficiency-induced root branching that enhances Fe-deficiency tolerance in tomato plants. J. Exp. Bot. 62, 3875-3884. doi: 10.1093/jxb/err078

Jurczyk, B., Rapacz, M., and Krepski, T. (2015). Photosynthetic apparatus responses to short-term low-temperature flooding may contribute to freezing tolerance changes in forage grasses. J. Agron. Crop Sci. 201, 45-96. doi: 10.1111/jac.12089

Kane, K., Dahal, K. P., Badawi, M. A., Houde, M., Hüner, N. P. A., and Sarhan, F. (2013). Long-term growth under elevated $\mathrm{CO}_{2}$ suppresses biotic stress genes in non-acclimated, but not cold-acclimated winter wheat. Plant Cell Physiol. 54, 1751-1768. doi: 10.1093/pcp/pct116

Kosová, K., Vítámvás, P., Planchon, S., Renaut, J., Vanková, R., and Prášil, I. T. (2013). Proteome analysis of cold response in spring and winter wheat (Triticum aestivum) crowns reveals similarities in stress adaptation and differences in regulatory processes between the growth habits. J. Proteome Res. 12, 4830-4845. doi: $10.1021 / \mathrm{pr} 400600 \mathrm{~g}$

Li, X., Cai, J., Liu, F., Dai, T., Cao, W., and Jiang, D. (2014a). Cold priming drives the sub-cellular antioxidant systems to protect photosynthetic electron transport against subsequent low temperature stress in winter wheat. Plant Physiol. Biochem. 82, 34-43. doi: 10.1016/j.plaphy.2014.05.005

Li, X., Cai, J., Liu, F. L., Dai, T. B., Cao, W. X., and Jiang, D. (2014b). Exogenous $\mathrm{ABA}$ application during grain filling in winter wheat improves cold tolerance of offspring's seedlings. J. Agron. Crop Sci. 200, 467-478. doi: 10.1111/jac. 12064

Li, X. N., Hao, C. L., Zhong, J. W., Liu, F. L., Cai, J., Wang, X., et al. (2015). Mechano-stimulated modifications in the chloroplast antioxidant system and proteome changes are associated with cold response in wheat. BMC Plant Biol. 15:219. doi: 10.1186/s12870-015-0610-6

Li, X. N., Jiang, H., Liu, F. L., Cai, J., Dai, T. B., Cao, W. X., et al. (2013). Induction of chilling tolerance in wheat during germination by pre-soaking seed with nitric oxide and gibberellin. Plant Growth Regul. 71, 31-40. doi: 10.1007/s10725-0139805-8

Liao, Y. W. K., Sun, Z. H., Zhou, Y. H., Shi, K., Li, X., Zhang, G. Q., et al. (2013). The role of hydrogen peroxide and nitric oxide in the induction of plant-encoded RNA-dependent RNA polymerase 1 in the basal defense against Tobacco Mosaic Virus. PLoS ONE 8:e76090. doi: 10.1371/journal.pone.0076090

Lin, C.-C., Jih, P.-J., Lin, H.-H., Lin, J.-S., Chang, L.-L., Shen, Y.-H., et al. (2011). Nitric oxide activates superoxide dismutase and ascorbate peroxidase to repress the cell death induced by wounding. Plant Mol. Biol. 77, 235-249. doi: 10.1007/ s11103-011-9805-x

Mai, V. C., Drzewiecka, K., Jeleń, H., Narożna, D., Rucińska-Sobkowiak, R., Kêsy, J., et al. (2014). Differential induction of Pisum sativum defense signaling molecules in response to pea aphid infestation. Plant Sci. 221, 1-12. doi: 10. 1016/j.plantsci.2014.01.011

Mignolet-Spruyt, L., Xu, E., Idänheimo, N., Hoeberichts, F. A., Mühlenbock, P., Brosché, M., et al. (2016). Spreading the news: subcellular and organellar reactive oxygen species production and signalling. J. Exp. Bot. 67, 3831-3844. doi: 10.1093/jxb/erw080

Miller, G., Schlauch, K., Tam, R., Cortes, D., Torres, M. A., Shulaev, V., et al. (2009). The plant NADPH oxidase RBOHD mediates rapid systemic signaling in response to diverse stimuli. Sci. Signal. 2, A26-A35. doi: 10.1126/scisignal. 2000448

Minibayeva, F., Kolesnikov, O., Chasov, A., Beckett, R. P., Lüthje, S., Vylegzhanina, N., et al. (2009). Wound-induced apoplastic peroxidase activities: their roles in the production and detoxification of reactive oxygen species. Plant Cell Environ. 32, 497-508. doi: 10.1111/j.1365-3040.2009.01944.x

Mittler, R., and Blumwald, E. (2015). The roles of ROS and ABA in systemic acquired acclimation. Plant Cell 27, 64-70. doi: 10.1105/tpc.114.133090

Mittler, R., Vanderauwera, S., Gollery, M., and Breusegem, F. V. (2004). Reactive oxygen gene network of plants. Trends Plant Sci. 9, 490-498. doi: 10.1016/j. tplants.2004.08.009

Mittler, R., Vanderauwera, S., Suzuki, N., Miller, G., Tognetti, V. B., Vandepoele, K., et al. (2011). ROS signaling: the new wave? Trends Plant Sci. 16, 300-309. doi: $10.1016 /$ j.tplants.2011.03.007

Mousavi, S. A. R., Chauvin, A., Pascaud, F., Kellenberger, S., and Farmer, E. E. (2013). GLUTAMATE RECEPTOR-LIKE genes mediate leaf-to-leaf wound signalling. Nature 500, 422-426. doi: 10.1038/nature12478
Nabity, P. D., Zavala, J. A., and Delucia, E. H. (2009). Indirect suppression of photosynthesis on individual leaves by arthropod herbivory. Ann. Bot. 103, 655-663. doi: 10.1093/aob/mcn127

Nakano, Y., and Asada, K. (1981). Hydrogen peroxide is scavenged by ascorbatespecific peroxidase in spinach chloroplasts. Plant Cell Physiol. 22, 867-880. doi: 10.1093/oxfordjournals.pcp.a076232

Neill, S. J., Desikan, R., and Hancock, J. T. (2002). Hydrogen peroxide signalling. Curr. Opin. Plant Biol. 5, 388-395. doi: 10.1016/S1369-5266(02)00282-0

Orozco-Cárdenas, M. L., Narváez-Vásquez, J., and Ryan, C. A. (2001). Hydrogen peroxide acts as a second messenger for the induction of defense genes in tomato plants in response to wounding, systemin, and Methyl Jasmonate. Plant Cell 13, 179-191. doi: 10.1105/tpc.13.1.179

Orozco-Cárdenas, M. L., and Ryan, C. A. (1999). Hydrogen peroxide is generated systemically in plant leaves by wounding and systemin via the octadecanoid pathway. Proc. Natl. Acad. U.S.A. 96, 6553-6557. doi: 10.1073/pnas.96.11.6553

Orozco-Cárdenas, M. L., and Ryan, C. A. (2002). Nitric oxide negatively modulates wound signaling in tomato plants. Plant Physiol. 130, 487-493. doi: 10.1104/pp. 008375

París, R., Lamattina, L., and Casalongué, C. A. (2007). Nitric oxide promotes the wound-healing response of potato leaflets. Plant Physiol. Biochem. 45, 80-86. doi: 10.1016/j.plaphy.2006.12.001

Pasqualini, S., Meier, S., Gehring, C., Madeo, L., Fornaciari, M., Romano, B., et al. (2009). Ozone and nitric oxide induce cGMP-dependent and-independent transcription of defence genes in tobacco. New Phytol. 181, 860-870. doi: 10. 1111/j.1469-8137.2008.02711.x

Patra, H. K., Kar, M., and Mishra, D. (1978). Catalase activity in leaves and cotyledons during plant development and senescence. Biochem. Physiol. Pflanzen 172, 385-390. doi: 10.1016/S0015-3796(17)30412-2

Prasad, T. K., Anderson, M. D., Martin, B. A., and Stewart, C. R. (1994). Evidence for chilling-induced oxidative stress in maize seedlings and a regulatory role for hydrogen peroxide. Plant Cell 6, 65-74. doi: 10.1105/tpc.6.1.65

Puyaubert, J., and Baudouin, E. (2014). New clues for a cold case: nitric oxide response to low temperature. Plant Cell Environ. 37, 2623-2630. doi: 10.1111/ pce.12329

Rockel, P., Strube, F., Rockel, A., Wildt, J., and Kaiser, W. M. (2002). Regulation of nitric oxide $(\mathrm{NO})$ production by plant nitrate reductase in vivo and in vitro. J. Exp. Bot. 53, 103-110. doi: 10.1093/jexbot/53.366.103

Rossel, J. B., Wilson, P. B., Hussain, D., Woo, N. S., Gordon, M. J., Mewett, O. P., et al. (2007). Systemic and intracellular responses to photooxidative stress in Arabidopsis. Plant Cell 19, 4091-4110. doi: 10.1105/tpc.106.045898

Rustérucci, C., Espunya, M. C., Díaz, M., Chabannes, M., and Martínez, M. C. (2007). S-Nitrosoglutathione reductase affords protection against pathogens in Arabidopsis, both locally and systemically. Plant Physiol. 143, 1282-1292. doi: 10.1104/pp.106.091686

Sagi, M., Davydov, O., Orazova, S., Yesbergenova, Z., Ophir, R., Stratmann, J. W., et al. (2004). Plant respiratory burst oxidase homologs impinge on wound responsiveness and development in Lycopersicon esculentum. Plant Cell 16, 616-628. doi: 10.1105/tpc.019398

Scheible, W.-R., Lauerer, M., Schulze, E.-D., Caboche, M., and Stitt, M. (1997). Accumulation of nitrate in the shoot acts as a signal to regulate shoot-root allocation in tobacco. Plant J. 11, 671-691. doi: 10.1046/j.1365-313X.1997. 11040671.x

Schilmiller, A. L., and Howe, G. A. (2005). Systemic signaling in the wound response. Curr. Opin. Plant Biol. 8, 369-377. doi: 10.1016/j.pbi.2005.05.008

Shen, W., Nada, K., and Tachibana, S. (2000). Involvement of polyamines in the chilling tolerance of cucumber cultivars. Plant Physiol. 124, 431-439. doi: 10. 1104/pp.124.1.431

Shi, S. Y., Wang, G., Wang, Y. D., Zhang, L. G., and Zhang, L. X. (2005). Protective effect of nitric oxide against oxidative stress under ultraviolet-B radiation. Nitric Oxide 13, 1-9. doi: 10.1016/j.niox.2005.04.006

Stewart, R. R. C., and Bewley, J. D. (1980). Lipid peroxidation associated with accelerated aging of soybean axes. Plant Physiol. 65, 245-248. doi: 10.1104/pp. 65.2.245

Sun, C. L., Lu, L. L., Liu, L. J., Liu, W. J., Yu, Y., Liu, X. X., et al. (2014). Nitrate reductase-mediated early nitric oxide burst alleviates oxidative damage induced by aluminum through enhancement of antioxidant defenses in roots of wheat (Triticum aestivum). New Phytol. 201, 1240-1250. doi: 10.1111/nph.12597 
Suzuki, N., Koussevitzky, S., Mittler, R., and Miller, G. (2012). ROS and redox signalling in the response of plants to abiotic stress. Plant Cell Environ. 35, 259-270. doi: 10.1111/j.1365-3040.2011.02336.x

Suzuki, N., and Mittler, R. (2006). Reactive oxygen species and temperature stresses: a delicate balance between signaling and destruction. Physiol. Plant. 126, 45-51. doi: 10.1111/j.0031-9317.2005.00582.x

Thordal-Christensen, H., Zhang, Z., Wei, Y., and Collinge, D. B. (1997). Subcellular localization of $\mathrm{H} 2 \mathrm{O} 2$ in plants. $\mathrm{H}_{2} \mathrm{O}_{2}$ accumulation in papillae and hypersensitive response during the barley-powdery mildew interaction. Plant J. 11, 1187-1194. doi: 10.1046/j.1365-313X.1997.11061187.x

Torres, M. A., and Dangl, J. L. (2005). Functions of the respiratory burst oxidase in biotic interactions, abiotic stress and development. Curr. Opin. Plant Biol. 8, 397-403. doi: 10.1016/j.pbi.2005.05.014

Trischuk, R. G., Schilling, B. S., Low, N. H., Gray, G. R., and Gusta, L. V. (2014). Cold acclimation, de-acclimation and re-acclimation of spring canola, winter canola and winter wheat: The role of carbohydrates, cold-induced stress proteins and vernalization. Environ. Exp. Bot. 106, 156-163. doi: 10.1016/j. envexpbot.2014.02.013

Walley, J. W., Coughlan, S., Hudson, M. E., Covington, M. F., Kaspi, R., Banu, G., et al. (2007). Mechanical stress induces biotic and abiotic stress responses via a novel cis-element. PLoS Genet. 3:e172. doi: 10.1371/journal.pgen.0030172

Wang, F., Guo, Z., Li, H., Wang, M., Onac, E., Zhou, J., et al. (2016). Phytochrome $\mathrm{A}$ and $\mathrm{B}$ function antagonistically to regulate cold tolerance via abscisic aciddependent jasmonate signaling. Plant Physiol. 170, 459-471. doi: 10.1104/pp. 15.01171

Willekens, H., Chamnongpol, S., Davey, M., Schraudner, M., Langebartels, C., Van Montagu, M., et al. (1997). Catalase is a sink for $\mathrm{H}_{2} \mathrm{O}_{2}$ and is indispensable for stress defence in C3 plants. EMBO J. 16, 4806-4816. doi: 10.1093/emboj/16.16. 4806

Xia, X. J., Zhou, Y. H., Ding, J., Shi, K., Asami, T., Chen, Z. X., et al. (2011). Induction of systemic stress tolerance by brassinosteroid in Cucumis sativus. New Phytol. 191, 706-720. doi: 10.1111/j.1469-8137.2011.03745.x

Xia, X. J., Zhou, Y. H., Shi, K., Zhou, J., Foyer, C. H., and Yu, J. Q. (2015). Interplay between reactive oxygen species and hormones in the control of plant development and stress tolerance. J. Exp. Bot. 66, 2839-2856. doi: 10.1093/jxb/ erv089

Zangerl, A. R., Hamilton, J. G., Miller, T. J., Crofts, A. R., Oxborough, K., Berenbaum, M. R., et al. (2002). Impact of folivory on photosynthesis is greater than the sum of its holes. Proc. Natl. Acad. U.S.A. 99, 1088-1091. doi: 10.1073/ pnas.022647099
Zhang, A. Y., Jiang, M. Y., Zhang, J. H., Ding, H. D., Xu, S. C., Hu, X. L., et al. (2007). Nitric oxide induced by hydrogen peroxide mediates abscisic acidinduced activation of the mitogen-activated protein kinase cascade involved in antioxidant defense in maize leaves. New Phytol. 175, 36-50. doi: 10.1111/ j.1469-8137.2007.02071.x

Zhang, J., Luo, W., Zhao, Y., Xu, Y., Song, S., and Chong, K. (2016). Comparative metabolomic analysis reveals a reactive oxygen species-dominated dynamic model underlying chilling environment adaptation and tolerance in rice. New Phytol. 211, 1295-1310. doi: 10.1111/nph.14011

Zhao, L. Q., Zhang, F., Guo, J. K., Yang, Y. L., Li, B. B., and Zhang, L. X. (2004). Nitric oxide functions as a signal in salt resistance in the calluses from two ecotypes of reed. Plant Physiol. 134, 849-857. doi: 10.1104/pp.103. 030023

Zhao, M. G., Chen, L., Zhang, L. L., and Zhang, W. H. (2009). Nitric reductasedependent nitric oxide production is involved in cold acclimation and freezing tolerance in Arabidopsis. Plant Physiol. 151, 755-767. doi: 10.1104/pp.109. 140996

Zhong, X., Mei, X., Li, Y., Yoshida, H., Zhao, P., Wang, X., et al. (2008). Changes in frost resistance of wheat young ears with development during jointing stage. J. Agron. Crop Sci. 194, 343-349. doi: 10.1111/j.1439-037X.2008.00320.x

Zhou, J., Wang, J., Shi, K., Xia, X. J., Zhou, Y. H., and Yu, J. Q. (2012). Hydrogen peroxide is involved in the cold acclimation-induced chilling tolerance of tomato plants. Plant Physiol. Biochem. 60, 141-149. doi: 10.1016/j.plaphy.2012. 07.010

Zhou, J., Xia, X. J., Zhou, Y. H., Shi, K., Chen, Z. X., and Yu, J. Q. (2014). RBOH1dependent $\mathrm{H}_{2} \mathrm{O}_{2}$ production and subsequent activation of MPK1/2 play an important role in acclimation-induced cross-tolerance in tomato. J. Exp. Bot. 65, 595-607. doi: 10.1093/jxb/ert404

Conflict of Interest Statement: The authors declare that the research was conducted in the absence of any commercial or financial relationships that could be construed as a potential conflict of interest.

Copyright (C) 2017 Si, Wang, Wu, Zhao, Zhang, Huang, Cai, Zhou, Dai, Zhu and Jiang. This is an open-access article distributed under the terms of the Creative Commons Attribution License (CC BY). The use, distribution or reproduction in other forums is permitted, provided the original author(s) or licensor are credited and that the original publication in this journal is cited, in accordance with accepted academic practice. No use, distribution or reproduction is permitted which does not comply with these terms. 